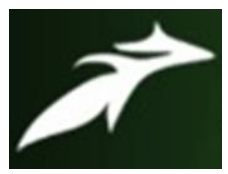

Anurag Shankar Singh et al, International Journal of Advances in Agricultural Science and Technology,

Vol.8 Issue.4, April-2021, pg. 22-52

ISSN: 2348-1358

Impact Factor: 6.057

NAAS Rating: 3.77

\title{
Socio-Economic Characteristics of Gram Panchayat Members at Hanumanganj Block of Ballia District of Uttar Pradesh
}

\author{
Anurag Shankar Singh* \\ M. Sc. Ag. (Agricultural Extension and Communication) \\ Dr. Syed H. Mazhar** \\ (Associate Professor) \\ Department of Agricultural Extension and Communication, SHUATS (Prayagraj) \\ DOI: 10.47856/ijaast.2021.v08i4.003
}

\begin{abstract}
Introduction of Panchayat Raj was hailed as one of the most important political innovations in Independent India. It was also considered as a revolutionary step. Panchayat Raj is a system of local self-government wherein the people take upon themselves the responsibility for development. The Gram Panchayat has occupied an important place in taking people's political, economic, social, patriotic aspirations and emotions to the government in order to build a strongest nation ever. The study was based on both Primary and Secondary data. Descriptive research design has been used in the present study. The study revealed that majority of respondents were middle age people, having education up to junior high school and mostly dependent on farming for their income. A large sum of the respondents had very high annual income while few of the respondents had low annual income. It is concluded that the majority of the respondents belonged to the middle socio-economic status. Social participation of Gram Panchayat members were significant in Gram Panchayat activities. Majority of respondents daily use newspaper as a means of mass media exposure.

Keywords:- Panchayati Raj, Gram Panchayat, Descriptive Research Design.
\end{abstract}

\section{INTRODUCTION}

The Institution of Panchayats in India dates back to ancient history when it performed the role of a village government. During British regime, these Panchayats were relegated a subservient position as the foreign rulers set up local self-governments on the pattern of their own country. Mahatma Gandhi, Father of the Nation, conceived village Panchayats as a potential instrument for the socio-economic and political transformation of the rural society and cultivation of 


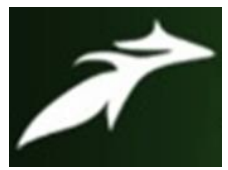

Anurag Shankar Singh et al, International Journal of Advances in Agricultural Science and Technology, Vol.8 Issue.4, April-2021, pg. 22-52

ISSN: 2348-1358

Impact Factor: 6.057

NAAS Rating: 3.77

democratic way of life at the grass-root level. Accordingly, the directive principles of state policy in our Indian Constitution enjoin the State to take steps to organize village Panchayats and endow them with such powers and authority as may be necessary to enable them to function as units of self-government. Pursuant to this Constitutional provisions many States enacted suitable legislation for setting up village Panchayats, while others amended the already existing law with a view to promoting quicker development of Panchayats and giving them a larger role than before. The community development projects, started by the Government of India on October 2, 1952, imparted a momentum to the movement of Panchayats. In 1958 Balwant Rai Mehta Committee recommended a three-tier Panchayat Raj system: Gram Panchayat at the lowest level, that is, the village; the Panchayat Samiti at the Community Development Block Level; and the Zila Parishad at the District level. These recommendations were endorsed by the National Development Council and consequently the Government of India's policy was based on these recommendations. The Constitutional base for PR was required because State Governments were not enthusiastic about the creation of PR bodies and having to share power with them. In fact, some States have taken power back from PR bodies. Status and dignity are essential to make these bodies viable and responsive institutions, and this requires Constitutional support. In India's Constitution, local self-government and Panchayati Raj was a State subject, and the Central Government could not pass any legislation concerning them. Hence, the 73rd Constitutional Amendment Act has been passed in 1993. The changes made by the 73rd and 74th Amendments in the Constitution are innovative and have given a new dimension to the system of governance at the local level in the country. (Bhatt, 2019)

\section{RESEARCH METHODOLOGY}

The present study was conducted in Hanumamganj block of Ballia district of Uttar Pradesh. 21 villages from Hanumanganj block were selected by Random sampling. Hanumanganj block and 126 respondents (6 respondents from each village) were selected for study. The study was based 


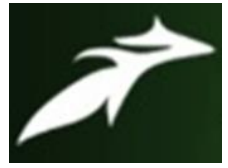

Anurag Shankar Singh et al, International Journal of Advances in Agricultural Science and Technology,

Vol.8 Issue.4, April-2021, pg. 22-52

ISSN: 2348-1358

Impact Factor: 6.057

NAAS Rating: 3.77

on both Primary and Secondary data. Descriptive research design has been used in the present study. The data was collected from respondents by using the pre structured interview schedule. Data analysis is done through frequency and percentage distribution using statistical tools.

For calculating percentage, frequency was multiplied by 100 and divided by total number of Respondents.

$$
\mathrm{P}=\mathrm{X} / \mathrm{N} \times 100
$$

Where,

$\mathrm{P}=$ Percentage

$\mathrm{X}=$ Frequency of the Respondents

$\mathrm{N}=$ Total number of Respondents

\section{RESULT AND DISCUSSION}

\section{Gender}

Table 1:-Distribution of the respondents based on gender

\begin{tabular}{|l|l|l|l|}
\hline S. No & Gender & Frequency & Percentage \\
\hline 1 & Male & 84 & 66.67 \\
\hline 2 & Female & 42 & 33.33 \\
\hline & Total & 126 & 100.00 \\
\hline
\end{tabular}




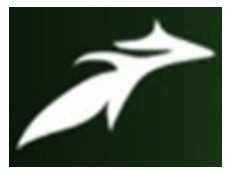

Anurag Shankar Singh et al, International Journal of Advances in Agricultural Science and Technology,

Vol.8 Issue.4, April-2021, pg. 22-52

ISSN: 2348-1358

Impact Factor: 6.057

NAAS Rating: 3.77

Figure 1:- Distribution of the respondents based on gender

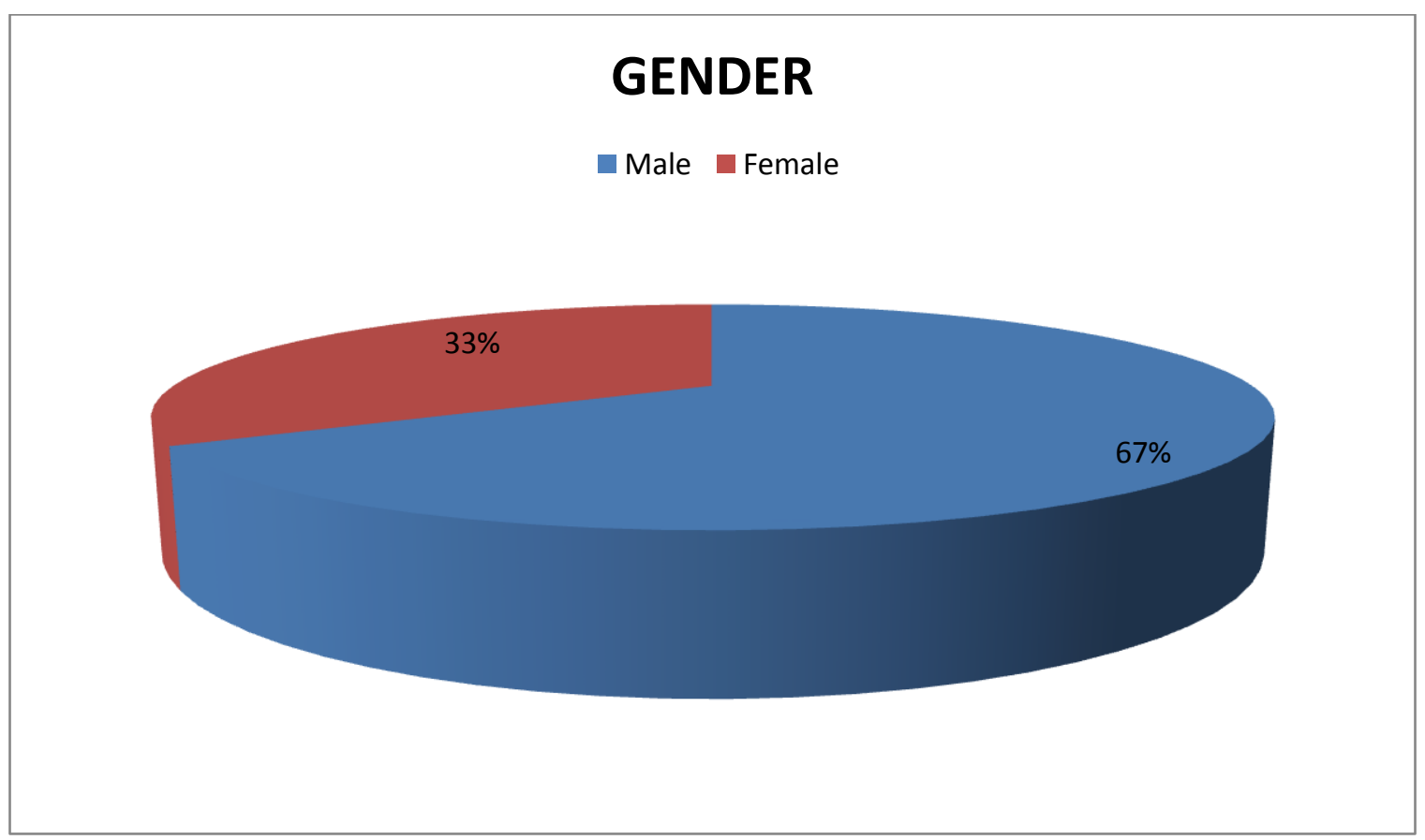

The result of the study presented in this chapter with facts observed during investigation and presented through table and pie chart. From the data furnished in table 1, it is concluded that majority of respondents were Male i.e. $66.67 \%$ and $33.33 \%$ respondents were Female. It is concluded that male respondents were more engaged in Gram Panchayat Activities as compared to female respondents. 


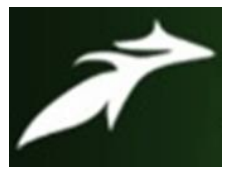

Anurag Shankar Singh et al, International Journal of Advances in Agricultural Science and Technology, Vol.8 Issue.4, April-2021, pg. 22-52

ISSN: 2348-1358

Impact Factor: 6.057

NAAS Rating: 3.77

\section{Age}

Table 2:- Distribution of the respondents based on age

\begin{tabular}{|l|l|l|l|}
\hline S. No & Age in years & Frequency & Percentage \\
\hline 1 & $21-35$ & 34 & 26.98 \\
\hline 2 & $36-55$ & 71 & 56.34 \\
\hline 3 & Above 55 & 21 & 16.67 \\
\hline & Total & 126 & 100.00 \\
\hline
\end{tabular}

Figure 2:- Distribution of the respondents based on age

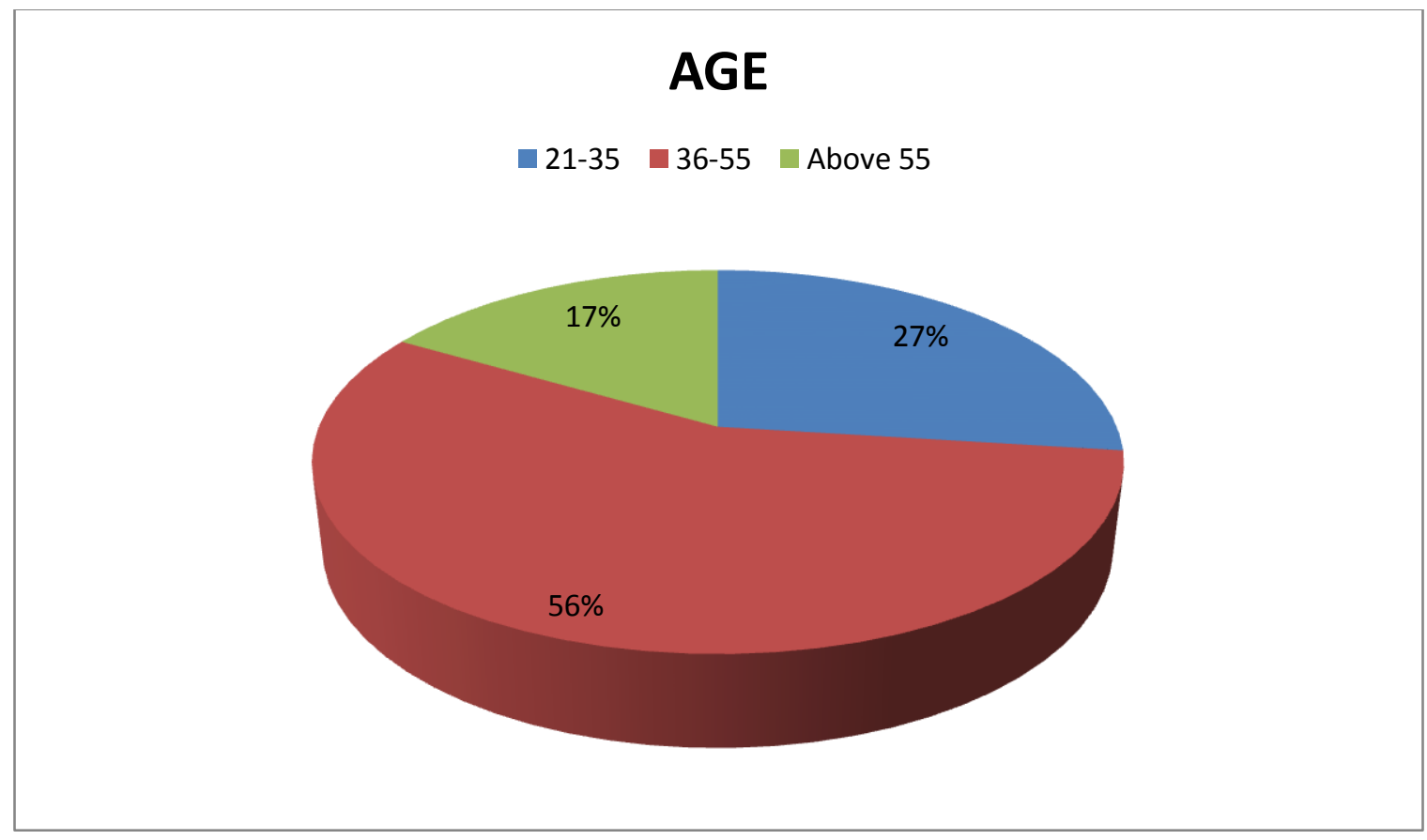

From the data mentioned in table 2 and pie chart shows that $26.98 \%$ respondents were of adult age between 21 to 35 years while $56.34 \%$ of the respondents are of middle age i.e. $36-55$ years 


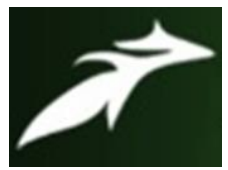

Anurag Shankar Singh et al, International Journal of Advances in Agricultural Science and Technology, Vol.8 Issue.4, April-2021, pg. 22-52

ISSN: 2348-1358

Impact Factor: 6.057

NAAS Rating: 3.77

and $16.67 \%$ of the respondents were of above 55. Similar findings is also reported by Bhagwat et al., in 2010.

\section{Caste}

Table 3:- Distribution of the respondents based on caste

\begin{tabular}{|l|l|l|l|}
\hline S. No & Caste & Frequency & Percentage \\
\hline 1 & General & 71 & 56.34 \\
\hline 2 & OBC & 53 & 42.06 \\
\hline 3 & SC & 02 & 1.58 \\
\hline & Total & 126 & 100.00 \\
\hline
\end{tabular}

Figure 3:- Distribution of the respondents based on caste

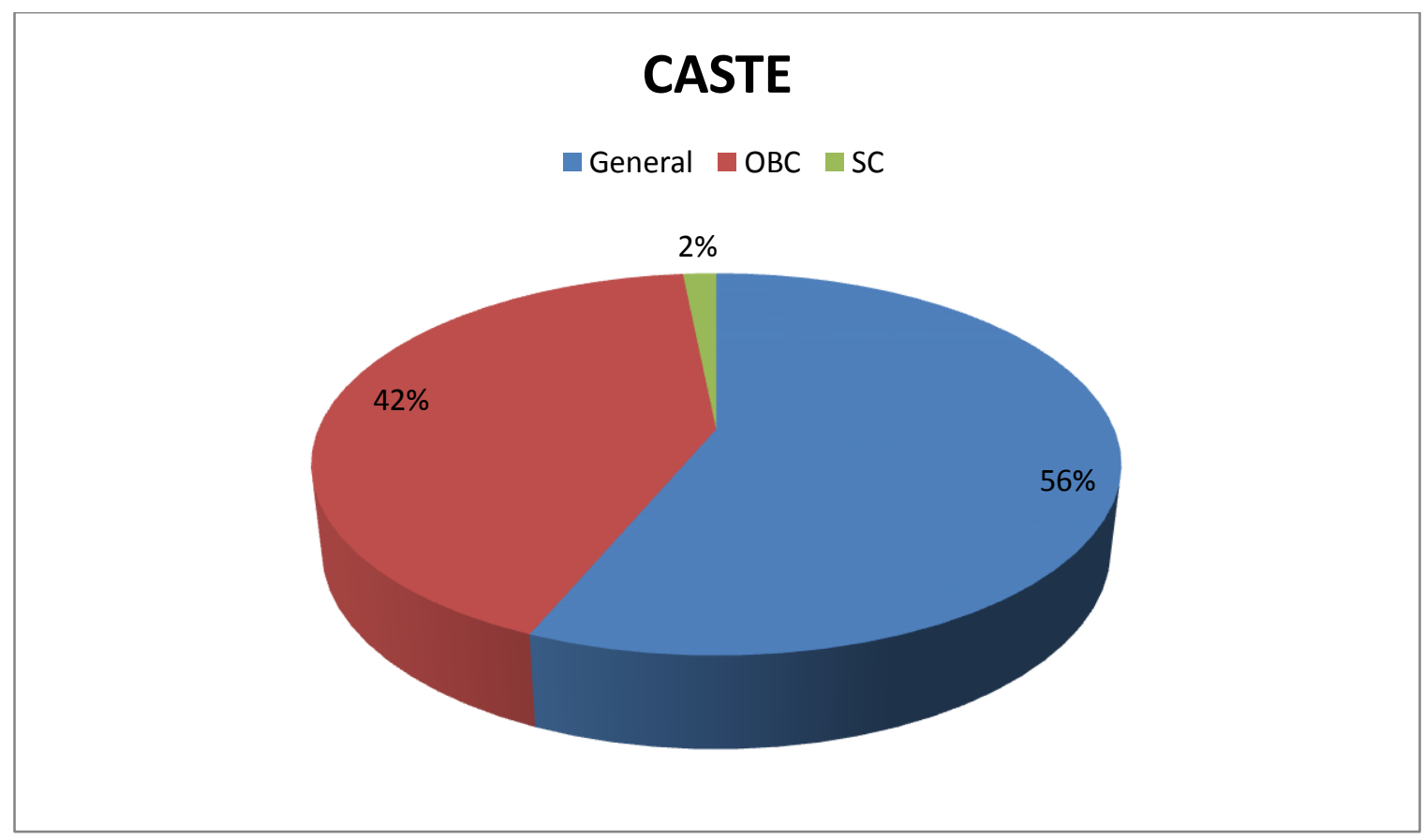




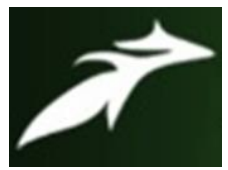

Anurag Shankar Singh et al, International Journal of Advances in Agricultural Science and Technology, Vol.8 Issue.4, April-2021, pg. 22-52

ISSN: 2348-1358

Impact Factor: 6.057

NAAS Rating: 3.77

From the data mentioned in table 3 and pie chart it is concluded that majority of respondents $56.34 \%$ belongs to General caste while $42.06 \%$ respondents belongs to Other Backward Class, rest $1.58 \%$ respondents belongs to scheduled caste.

\section{Marital status}

Table 4:- Distribution of the respondents based on marital status

\begin{tabular}{|l|l|l|l|}
\hline S. No. & Marital status & Frequency & Percentage \\
\hline 1 & Married & 117 & \\
\hline 2 & Unmarried & 09 & 92.85 \\
\hline & Total & 126 & 7.15 \\
\hline
\end{tabular}

Figure 4:- Distribution of the respondents based on marital status

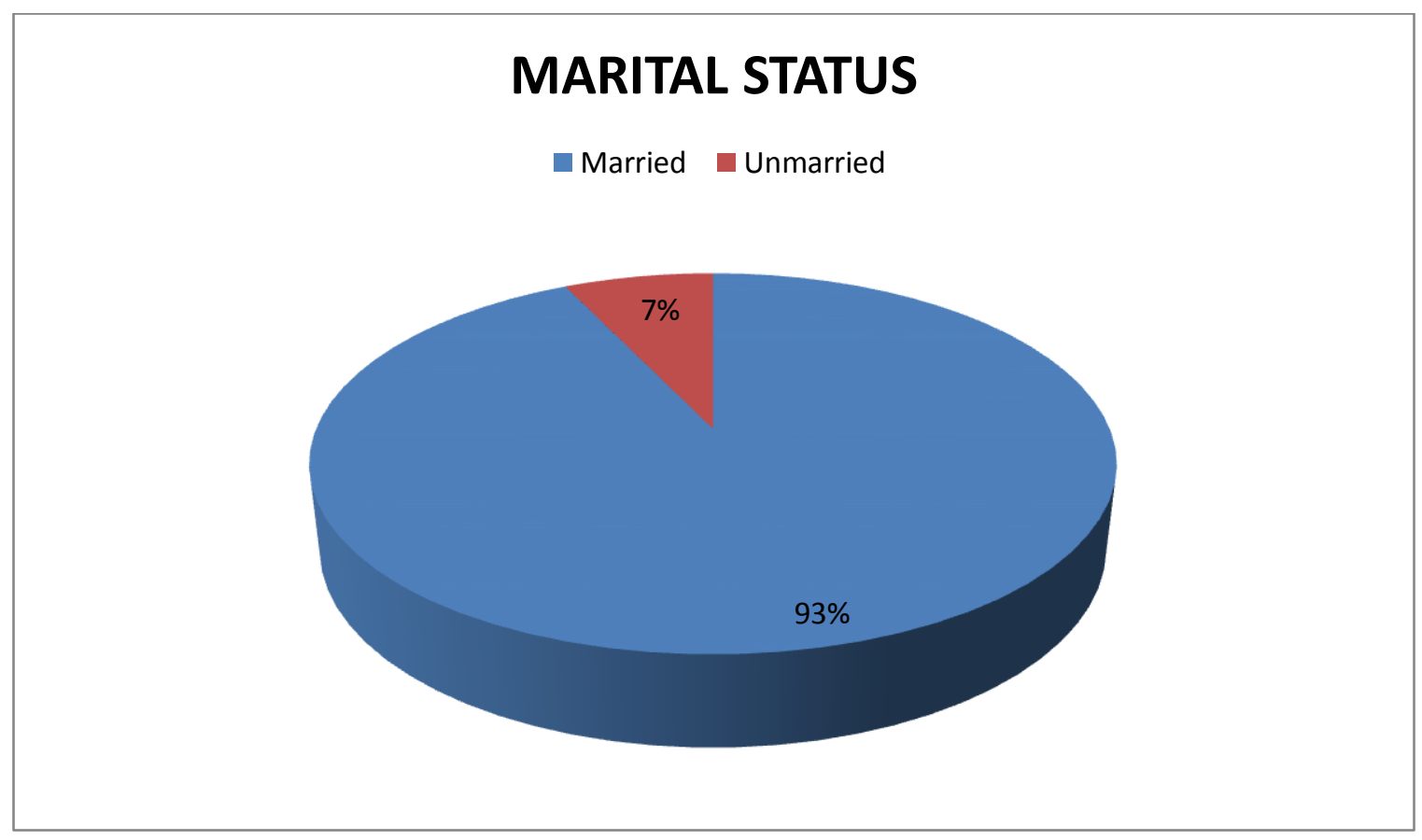




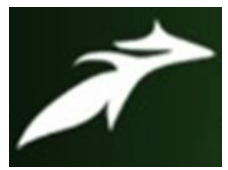

Anurag Shankar Singh et al, International Journal of Advances in Agricultural Science and Technology,

Vol.8 Issue.4, April-2021, pg. 22-52

ISSN: 2348-1358

Impact Factor: 6.057

NAAS Rating: 3.77

Data furnished in table 4 and pie chart shows that $92.85 \%$ respondents were married and $7.15 \%$ respondents were found unmarried. Among some unmarried respondents there were few female respondents who are at earlier age or their family is looking for groom. While in case of male respondents they were not married because they had younger sisters so firstly, they wanted to marry them before their marriage.

\section{Annual income}

Table 5:- Distribution of the respondents based on the Annual Income

\begin{tabular}{|l|l|l|l|}
\hline S. No & Annual income(in Rs) & Frequency & Percentage \\
\hline 1 & $20,000-60,000$ & 22 & 17.46 \\
\hline 2 & $60,001-1,20,000$ & 33 & 26.19 \\
\hline 3 & $1,20,001-1,80,000$ & 28 & 22.22 \\
\hline 4 & $1,80,001-2,40,000$ & 05 & 03.96 \\
\hline 5 & More than $2,40,000$ & 38 & 30.15 \\
\hline & Total & 126 & 100.00 \\
\hline
\end{tabular}




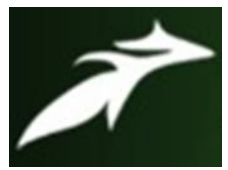

Anurag Shankar Singh et al, International Journal of Advances in Agricultural Science and Technology, Vol.8 Issue.4, April-2021, pg. 22-52

ISSN: 2348-1358

Impact Factor: 6.057

NAAS Rating: 3.77

Figure 5:- Distribution of the respondents based on the Annual Income

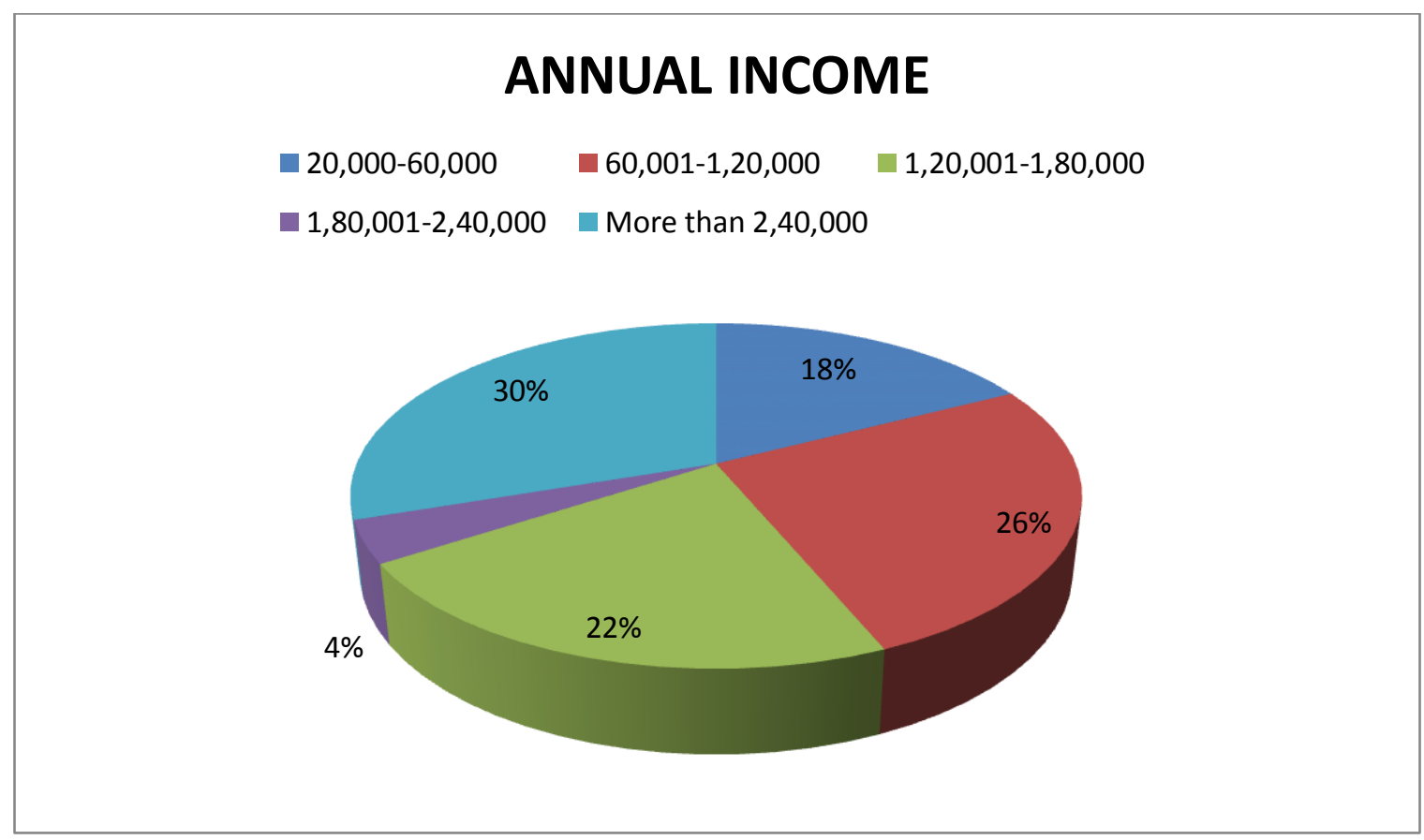

From the data furnished in table 5 and pie chart it is concluded that majority of respondents i.e. $30.15 \%$ were having more than 2,40,000 Rupees of Annual income, followed by $26.19 \%$ respondents having annual income in between 60,001-1,20,000 and 22.22\% respondents were having annual income in between 1,20,001-1,80,000. 17.46\% respondents were having annual income in between 20,000-60,000 followed by $03.96 \%$ respondents were having annual income in between 1,80,001-2,40,000. 


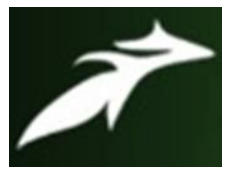

Anurag Shankar Singh et al, International Journal of Advances in Agricultural Science and Technology,

Vol.8 Issue.4, April-2021, pg. 22-52

ISSN: 2348-1358

Impact Factor: 6.057

NAAS Rating: 3.77

\section{Education}

Table 6:- Distribution of the respondents based on education

\begin{tabular}{|l|l|l|l|}
\hline S. No & Education & Frequency & Percentage \\
\hline 1 & Illiterate & 01 & 0.79 \\
\hline 2 & Primary & 31 & 24.60 \\
\hline 3 & Junior High School & 33 & 26.19 \\
\hline 4 & High School & 30 & 23.80 \\
\hline 5 & Intermediate & 15 & 11.90 \\
\hline 6 & Graduate and above & 16 & 12.69 \\
\hline & Total & 126 & 100.00 \\
\hline
\end{tabular}

Figure 6:- Distribution of the respondents based on education

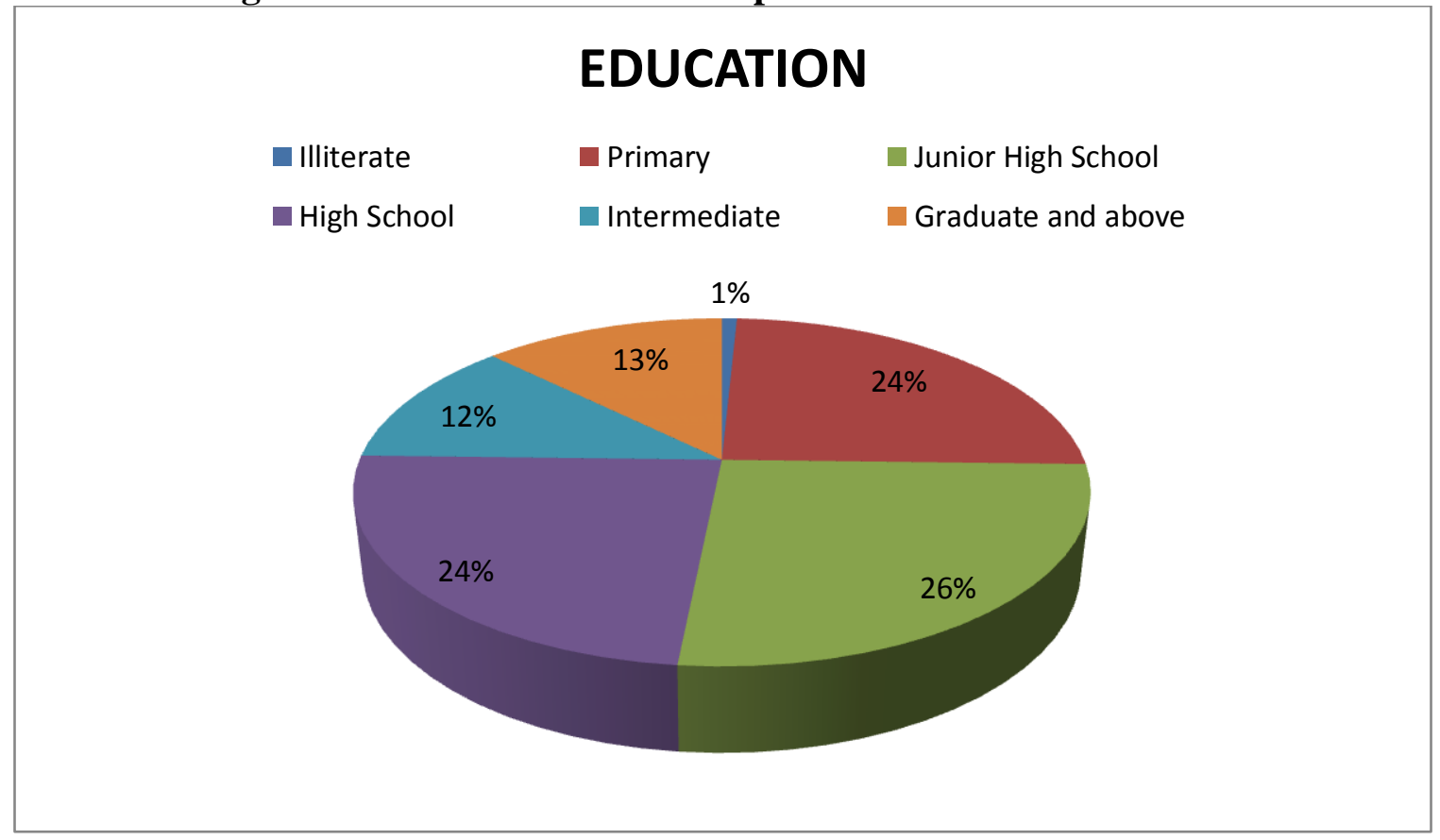




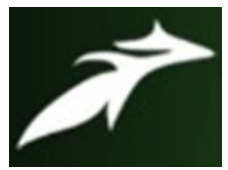

Anurag Shankar Singh et al, International Journal of Advances in Agricultural Science and Technology, Vol.8 Issue.4, April-2021, pg. 22-52

ISSN: 2348-1358

Impact Factor: 6.057

NAAS Rating: 3.77

The table 6 and pie chart shows that $0.79 \%$ respondents were illiterate, $24.60 \%$ were primary educated, and $26.19 \%$ has completed their junior high school education while $23.80 \%$ have completed their High school, 11.90\% respondents were of Intermediate education and 12.69\% of respondents were graduate and above educational qualification. Education level has also changed remarkably because of modernization in these area. The above figures show that though the illiteracy level amongst the respondents is very low, but still most of the respondents were primary and secondary educated. Few of them were also engaged in private coaching and teaching facilities.

\section{Total Land Holdings}

Table 7:- Distribution of total land holdings of the respondents

\begin{tabular}{|l|l|l|l|}
\hline S. No & Total Land holding & Frequency & Percentage \\
\hline 1 & Below 1 acre & 76 & 60.31 \\
\hline 2 & $1-2$ acres & 37 & 29.36 \\
\hline 3 & $2-3$ acres & 12 & 09.52 \\
\hline 4 & Above 3 acres & 01 & 0.79 \\
\hline & Total & 126 & 100.00 \\
\hline
\end{tabular}




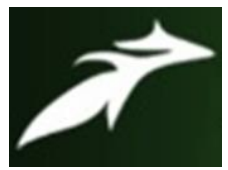

Anurag Shankar Singh et al, International Journal of Advances in Agricultural Science and Technology,

Vol.8 Issue.4, April-2021, pg. 22-52

ISSN: 2348-1358

Impact Factor: 6.057

NAAS Rating: 3.77

Figure 7:- Distribution of total land holdings of the respondents

\section{TOTAL LAND HOLDING}

$\square$ Below 1 acre $\quad 1-2$ acres $\quad$ 2-3 acres $\quad$ Above 3 acres

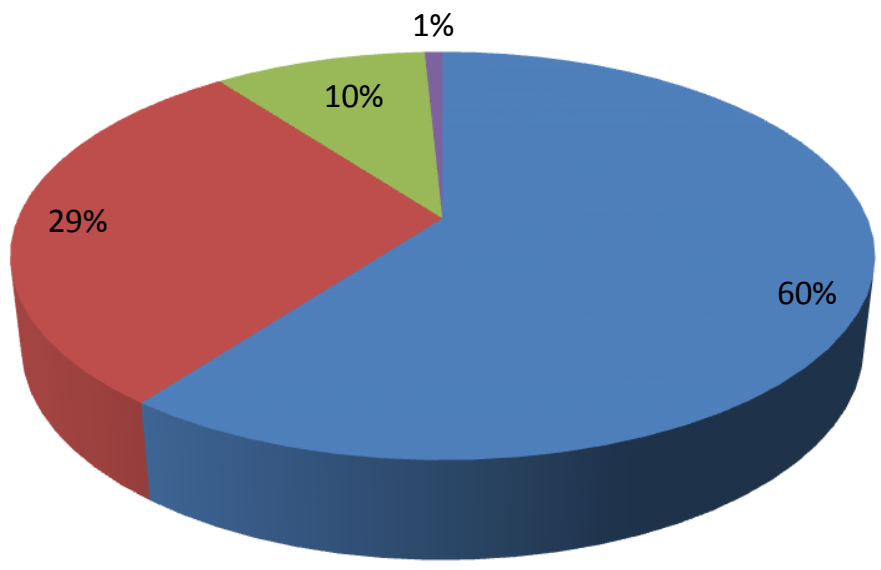

From the data furnished in table 7 and pie chart it is concluded that majority of respondents i.e. $60.31 \%$ were having below 1 acre of land, while $29.36 \%$ respondents were having 1-2 acres of land and $9.52 \%$ respondents were having $2-3$ acres of land and $0.79 \%$ of respondents were having above 3 acres of land.

\section{Occupation}

Table 8:- Distribution of the respondents based on occupation

\begin{tabular}{|l|l|l|l|}
\hline S.No & Occupation & Frequency & Percentage \\
\hline 1 & GPA+Farming & 74 & 58.73 \\
\hline 2 & GPA+Dairy & 21 & 16.67 \\
\hline
\end{tabular}




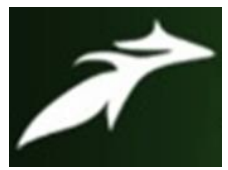

Anurag Shankar Singh et al, International Journal of Advances in Agricultural Science and Technology, Vol.8 Issue.4, April-2021, pg. 22-52

ISSN: 2348-1358

Impact Factor: 6.057

NAAS Rating: 3.77

\begin{tabular}{|l|l|l|l|}
\hline 3 & GPA+Other & $31^{`}$ & 24.60 \\
\hline & Total & 126 & 100.00 \\
\hline
\end{tabular}

GPA- Gram Panchayat Activities

Figure 8:- Distribution of the respondents based on occupation

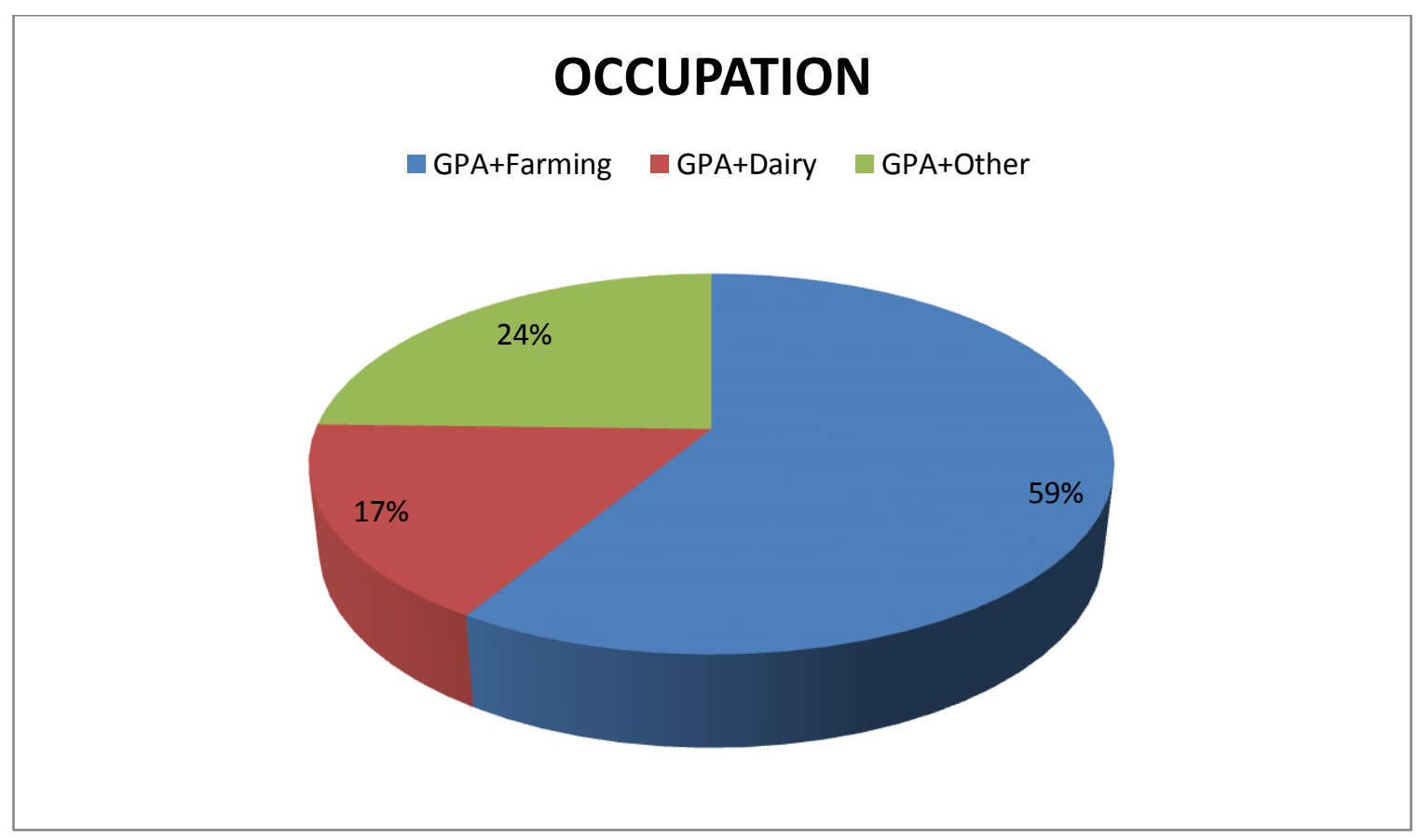

From the data furnished in table 8 and pie chart it is found that majority of respondents i.e. $58.73 \%$ were collectively engaged in Gram Panchayat Activities and farming and 16.67\% respondents were collectively engaged in Gram Panchayat Activities and dairy, rest 24.60\% respondents were collectively engaged in Gram Panchayat Activities and others activities. Since the respondents were Gram Panchayat Members so the main occupation of respondents were Gram Panchayat Activities. 


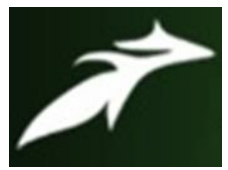

Anurag Shankar Singh et al, International Journal of Advances in Agricultural Science and Technology, Vol.8 Issue.4, April-2021, pg. 22-52

ISSN: 2348-1358

Impact Factor: 6.057

NAAS Rating: 3.77

\section{Family type}

Table 9:- Distribution of the respondents based on family type

\begin{tabular}{|l|l|l|l|}
\hline S. No & Family type & Frequency & Percentage \\
\hline 1 & Nuclear & 94 & 74.60 \\
\hline 2 & Joint & 32 & 25.40 \\
\hline & Total & 126 & 100.00 \\
\hline
\end{tabular}

Figure 9:- Distribution of the respondents based on family type

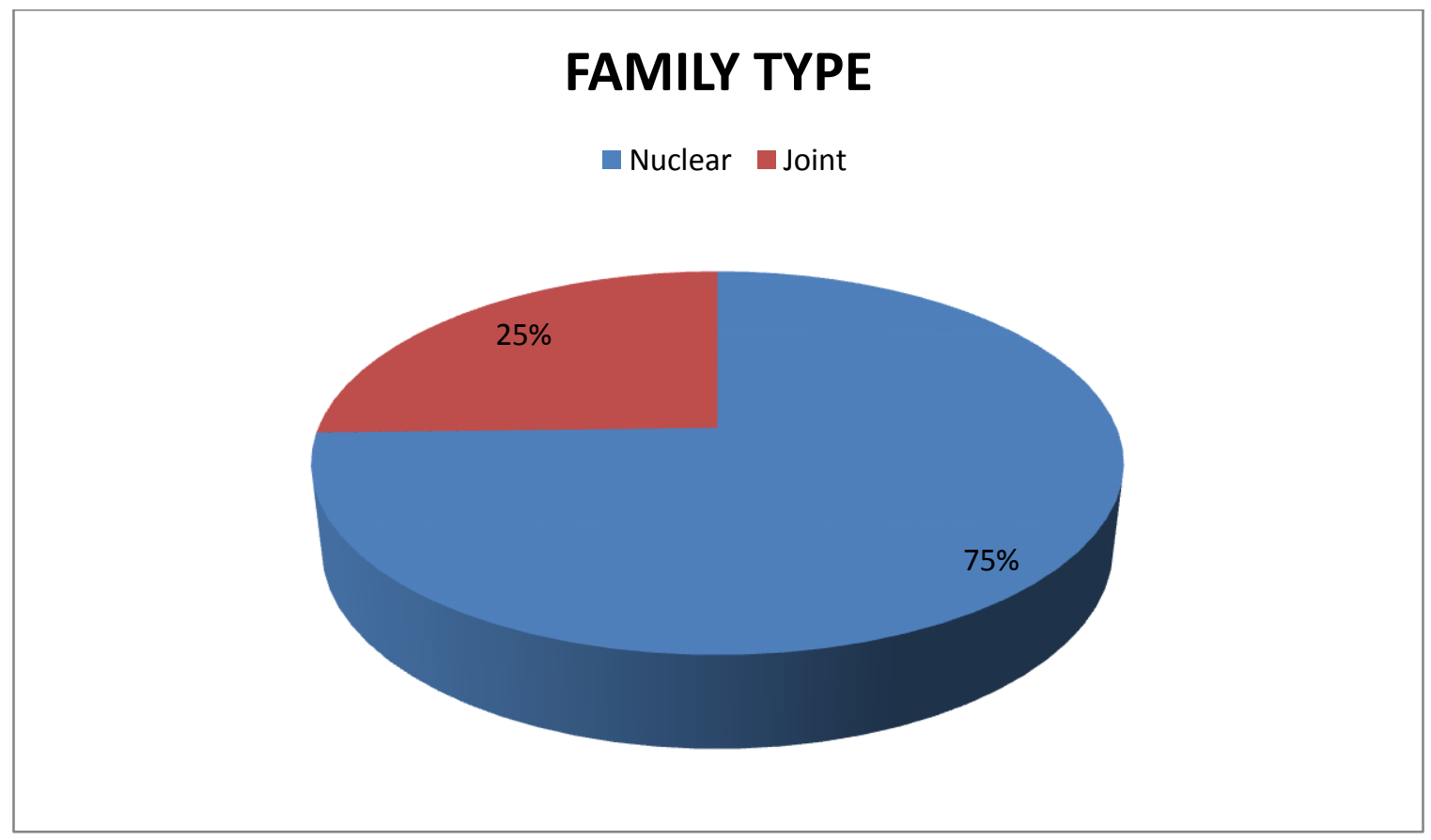

The table 9 and pie chart shows that $74.60 \%$ respondents had nuclear family and other $25.40 \%$ respondents had joint family. 


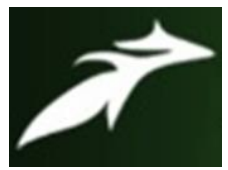

Anurag Shankar Singh et al, International Journal of Advances in Agricultural Science and Technology,

Vol.8 Issue.4, April-2021, pg. 22-52

ISSN: 2348-1358

Impact Factor: 6.057

NAAS Rating: 3.77

\section{Family size}

Table 10:- Distribution of the respondents based on the size of family

\begin{tabular}{|l|l|l|l|}
\hline S. No & Family size & Frequency & Percentage \\
\hline 1 & Up to 5 members & 92 & 73.01 \\
\hline 2 & More than 5 members & 34 & 26.99 \\
\hline & Total & 126 & 100.00 \\
\hline
\end{tabular}

Figure 10:- Distribution of the respondents based on the size of family

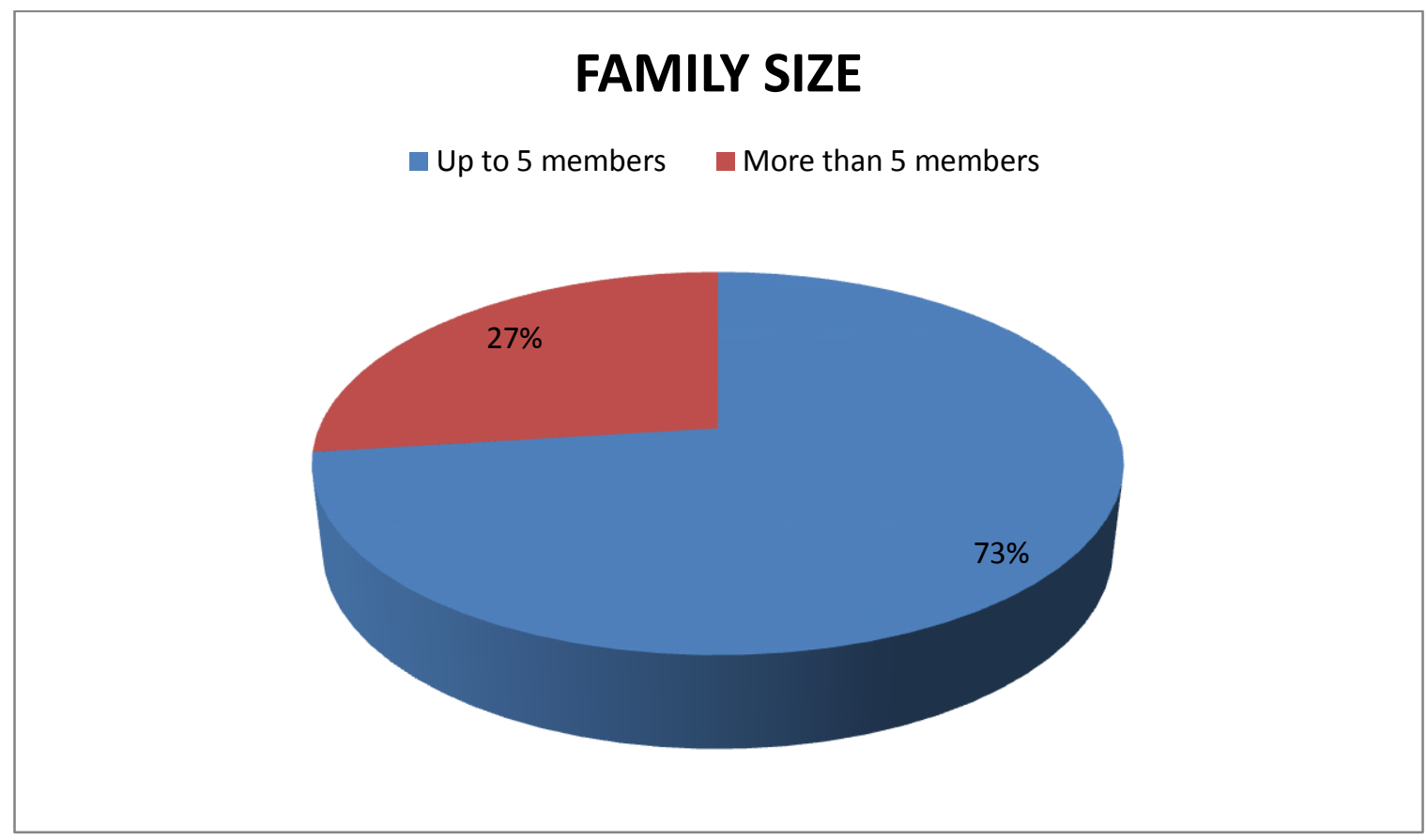

The table 10 and pie chart shows that $73.01 \%$ respondents had up to 5 members in their family and other $26.99 \%$ respondents had more than 5 members in their family. 


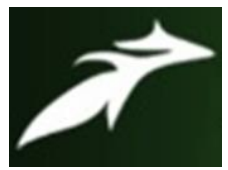

Anurag Shankar Singh et al, International Journal of Advances in Agricultural Science and Technology, Vol.8 Issue.4, April-2021, pg. 22-52

ISSN: 2348-1358

Impact Factor: 6.057

NAAS Rating: 3.77

11. Types of house

Table 11:- Distribution of the respondents based on type of House

\begin{tabular}{|l|l|l|l|}
\hline S. No & Type of house & Frequency & Percentage \\
\hline 1 & Semi -cemented & 50 & 39.68 \\
\hline 2 & Cemented & 76 & 60.32 \\
\hline & Total & 126 & 100.00 \\
\hline
\end{tabular}

Figure 11:- Distribution of the respondents based on type of House

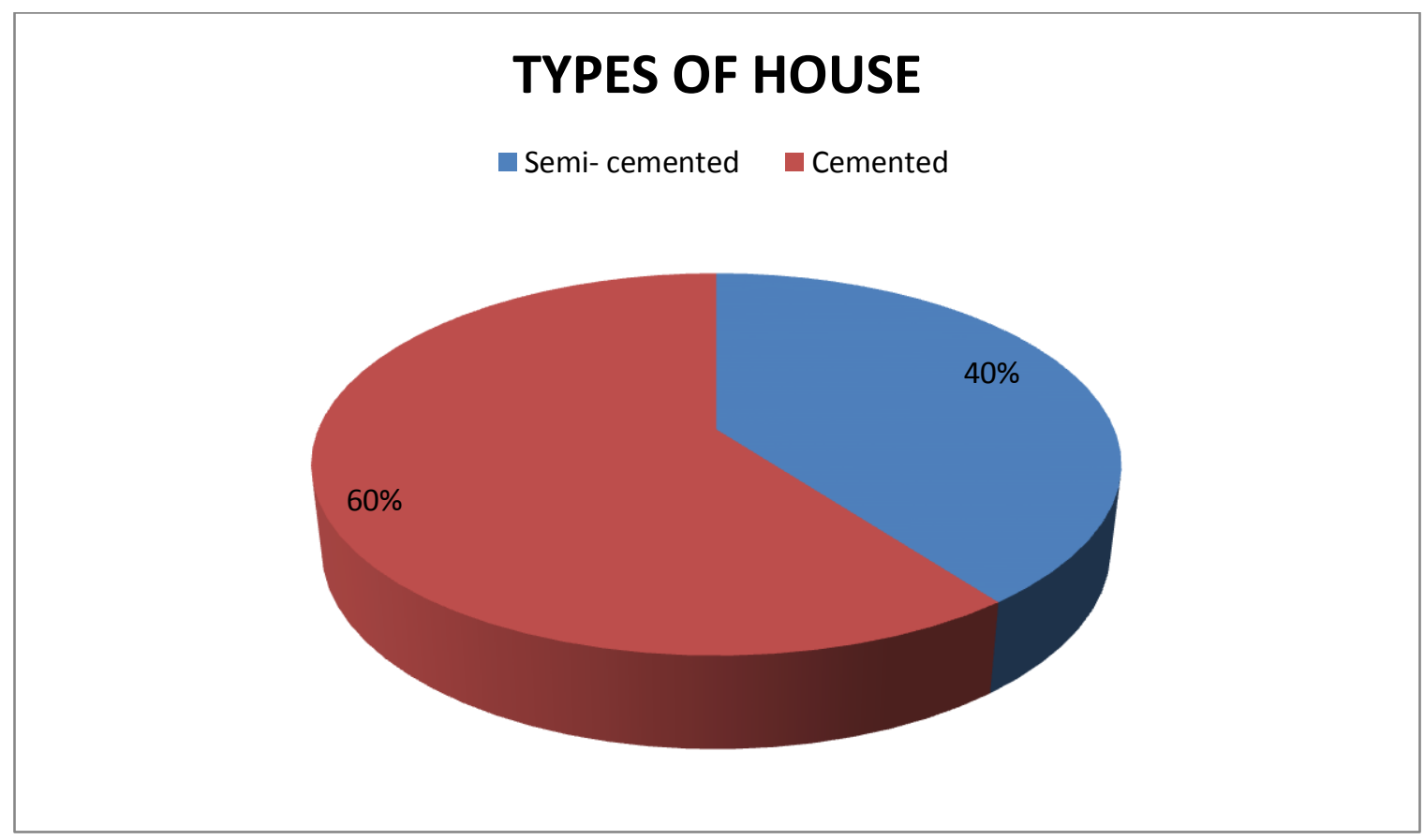

The results of the Housing Pattern of respondents were found during the study presented in table 11 and pie chart shows that $60.32 \%$ of the respondent had cemented house painted by multiple colours, while $39.68 \%$ of respondents had semi cemented house. 


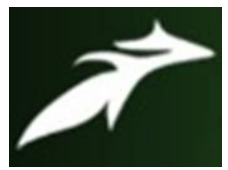

Anurag Shankar Singh et al, International Journal of Advances in Agricultural Science and Technology,

Vol.8 Issue.4, April-2021, pg. 22-52

ISSN: 2348-1358

Impact Factor: 6.057

NAAS Rating: 3.77

12. Social Participation

Table 12:- Distribution of respondents based on social participation

\begin{tabular}{|l|l|l|l|l|l|l|l|l|}
\hline \multirow{2}{*}{ S.No. } & \multirow{2}{*}{} & \multirow{2}{*}{ Organization } & \multirow{6}{*}{ Membership } & \multicolumn{2}{|c|}{$\begin{array}{c}\text { Fully } \\
\text { Participate }\end{array}$} & \multicolumn{2}{|c|}{$\begin{array}{c}\text { Partially } \\
\text { Participate }\end{array}$} & \multicolumn{2}{l|}{ Not Participate } \\
\cline { 4 - 10 } & & & F & P & F & P & F & P \\
\hline 1 & GP & Temporary & 126 & 100 & 00 & 00 & 00 & 00 \\
\hline 2 & ZP & Temporary & 00 & 00 & 28 & 22.22 & 98 & 77.78 \\
\hline 3 & SHG & Temporary & 03 & 2.38 & 11 & 8.94 & 112 & 88.88 \\
\hline 4 & ICDS & Temporary & 09 & 7.14 & 10 & 7.93 & 107 & 84.92 \\
\hline 5 & CS & Temporary & 00 & 00 & 08 & 6.34 & 118 & 93.65 \\
\hline
\end{tabular}

GP- Gram Panchayat, ZP- Zila Panchayat, SHG- Self Help Group, ICDS- Integrated community Development Scheme, CS- Cooperative society

F- Frequency, P- Percentage

Figure 12:- Distribution of respondents based on social participation

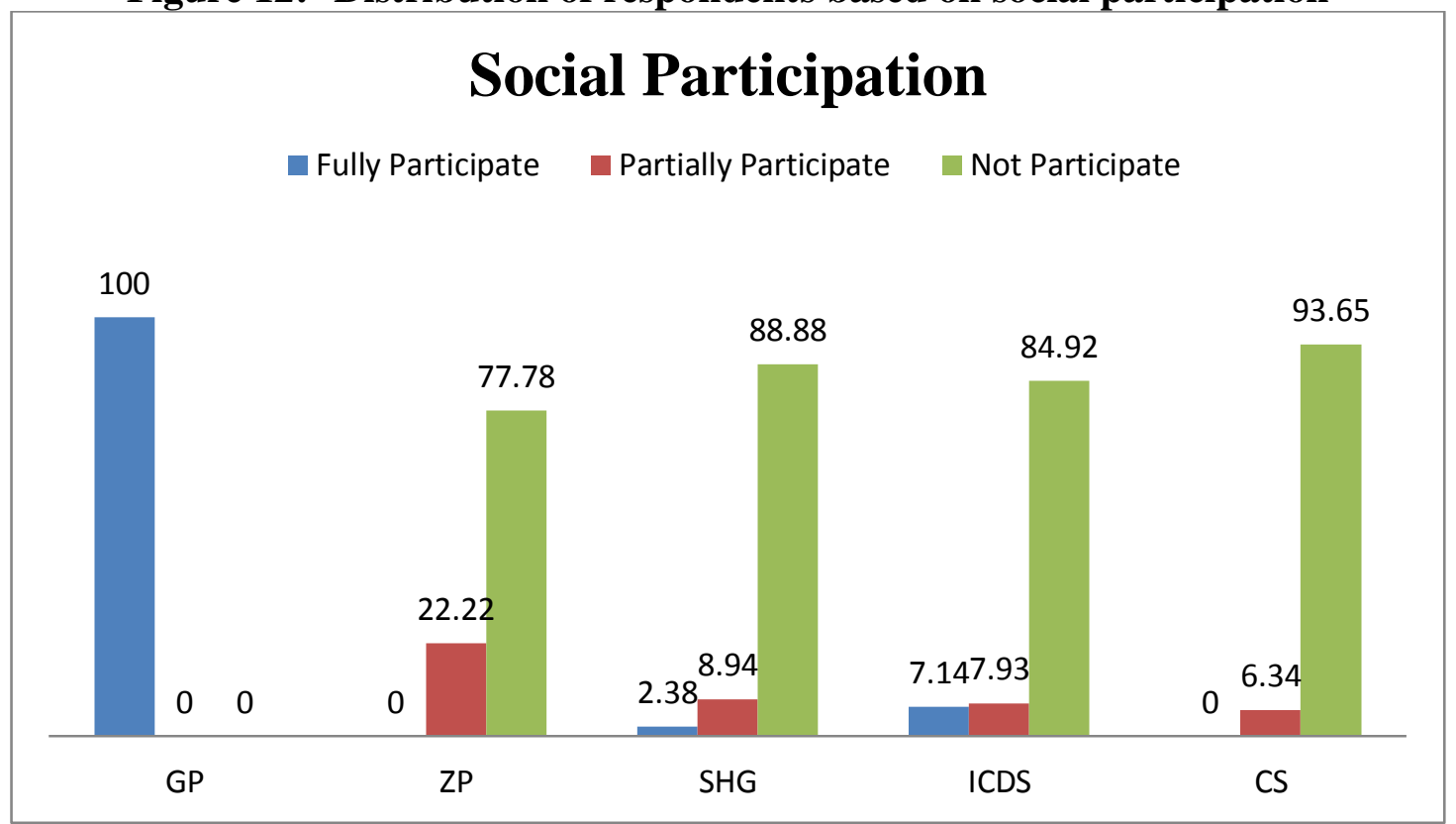




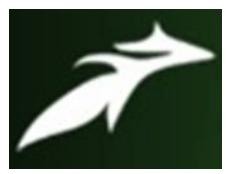

Anurag Shankar Singh et al, International Journal of Advances in Agricultural Science and Technology,

Vol.8 Issue.4, April-2021, pg. 22-52

ISSN: 2348-1358

Impact Factor: 6.057

NAAS Rating: 3.77

From the data furnished in table 12 and graph it is found that the participation of all respondents in each organization was temporary out of which $100 \%$ respondents were fully participated in Gram Panchayat, and none of them were fully participated in Zila Panchayat, 22.22\% of respondents partially participated in Zila Panchayat and $77.78 \%$ of respondents not participated in Zila Panchayat. 2.38\% of respondents were fully participated in Self Help Group(SHG), $8.94 \%$ of respondents partially participated in SHG, while $88.88 \%$ of respondents were not participated in SHG. 7.14\% of respondents were fully participated in Integrated community Development Scheme (ICDS), 7.93\% of respondents were partially participated in ICDS, while $84.92 \%$ of respondents were not participated in ICDS. None of the respondents were fully participated in cooperative societies (CS), while $6.34 \%$ of respondents were partially participated in CS and $93.65 \%$ of respondents were not participated in CS.

\section{Mass Media Exposure}

Table 13:- Distribution of respondents based on mass media exposure

\begin{tabular}{|c|c|c|c|c|c|c|c|}
\hline \multirow[t]{3}{*}{ S. No. } & \multirow{3}{*}{$\begin{array}{c}\text { Mass media } \\
\text { exposure }\end{array}$} & \multicolumn{6}{|c|}{ Listening/Viewing/Reading behavior } \\
\hline & & \multicolumn{2}{|c|}{ Daily } & \multicolumn{2}{|c|}{ Sometimes } & \multicolumn{2}{|c|}{ Never } \\
\hline & & $\mathbf{F}$ & $\mathbf{P}$ & $\mathbf{F}$ & $\mathbf{P}$ & $\mathbf{F}$ & $\mathbf{P}$ \\
\hline 1 & Radio & 00 & 00 & 28 & 22.22 & 98 & 77.77 \\
\hline 2 & Television & 15 & 11.90 & 56 & 44.44 & 55 & 43.65 \\
\hline 3 & Newspaper & 78 & 61.90 & 14 & 11.11 & 34 & 26.98 \\
\hline 4 & Magazines & 00 & 00 & 00 & 00 & 126 & 100.00 \\
\hline
\end{tabular}




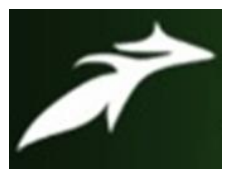

Anurag Shankar Singh et al, International Journal of Advances in Agricultural Science and Technology,

Vol.8 Issue.4, April-2021, pg. 22-52

ISSN: 2348-1358

Impact Factor: 6.057

NAAS Rating: 3.77

Figure 13:- Distribution of respondents based on mass media exposure

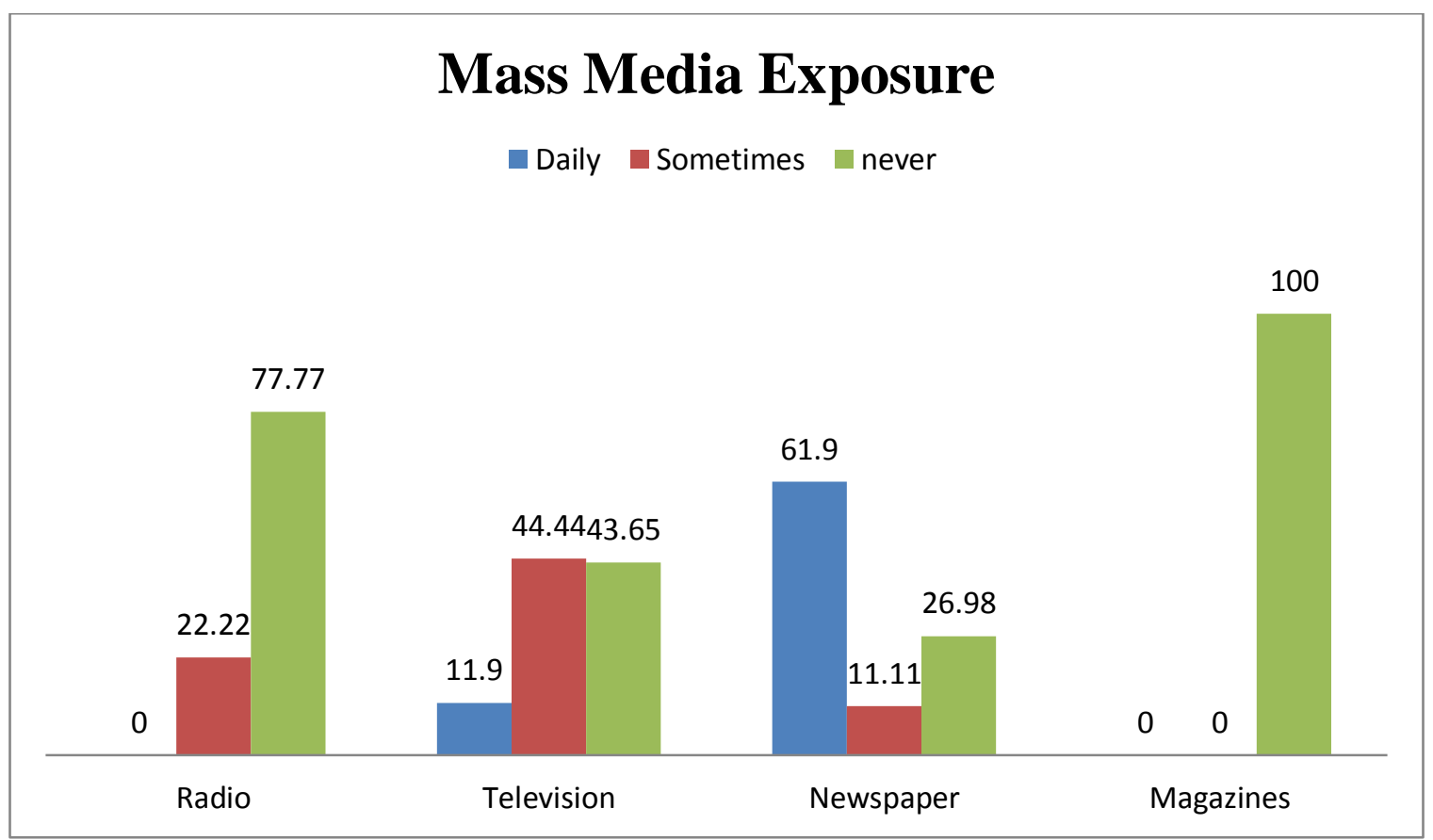

From the data mentioned in table 13 and graph it is found that none of the respondents were daily using radio as a means of mass media exposure, while $22.22 \%$ of respondents were sometimes using radio as a means of mass media exposure and $77.77 \%$ of respondents were never using radio as a means of mass media exposure. $11.90 \%$ of respondents were daily using television as a means of mass media exposure while $44.44 \%$ of respondents were sometimes using television as a means of mass media exposure and $43.65 \%$ of respondents were never using television as a means of mass media exposure. $61.90 \%$ of respondents were daily using newspaper as a means of mass media exposure while $11.11 \%$ of respondents sometimes using newspaper as a means of mass media exposure and $26.98 \%$ of respondents never using newspaper as a means of mass media exposure. None of respondents were neither daily nor sometimes using magazines as a means of mass media exposure. 


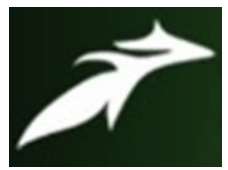

Anurag Shankar Singh et al, International Journal of Advances in Agricultural Science and Technology, Vol.8 Issue.4, April-2021, pg. 22-52

ISSN: 2348-1358

Impact Factor: 6.057

NAAS Rating: 3.77

14. Leadership Ability

Table 14:- Distribution of respondents based on leadership ability

\begin{tabular}{|l|l|l|l|l|l|}
\hline \multirow{2}{*}{ S. No. } & Activity/Institution & \multicolumn{5}{|c|}{ Leadership } \\
\cline { 3 - 6 } & & & Self & \multicolumn{5}{|l|}{ Collaborative } \\
\cline { 3 - 6 } & & F & P & F & P \\
\hline $\mathbf{1}$ & ZP & 00 & 00 & 126 & 100.00 \\
\hline $\mathbf{2}$ & BP & 00 & 00 & 126 & 100.00 \\
\hline $\mathbf{3}$ & GP & 126 & 100.00 & 00 & 00 \\
\hline $\mathbf{4}$ & BDC member & 126 & 100.00 & 00 & 00 \\
\hline
\end{tabular}

ZP- Zila Panchayat, BP- Block Panchayat, GP- Gram Panchayat, BDC- Block Development Council

F- Frequency, P- Percentage

Figure 14:- Distribution of respondents based on leadership ability

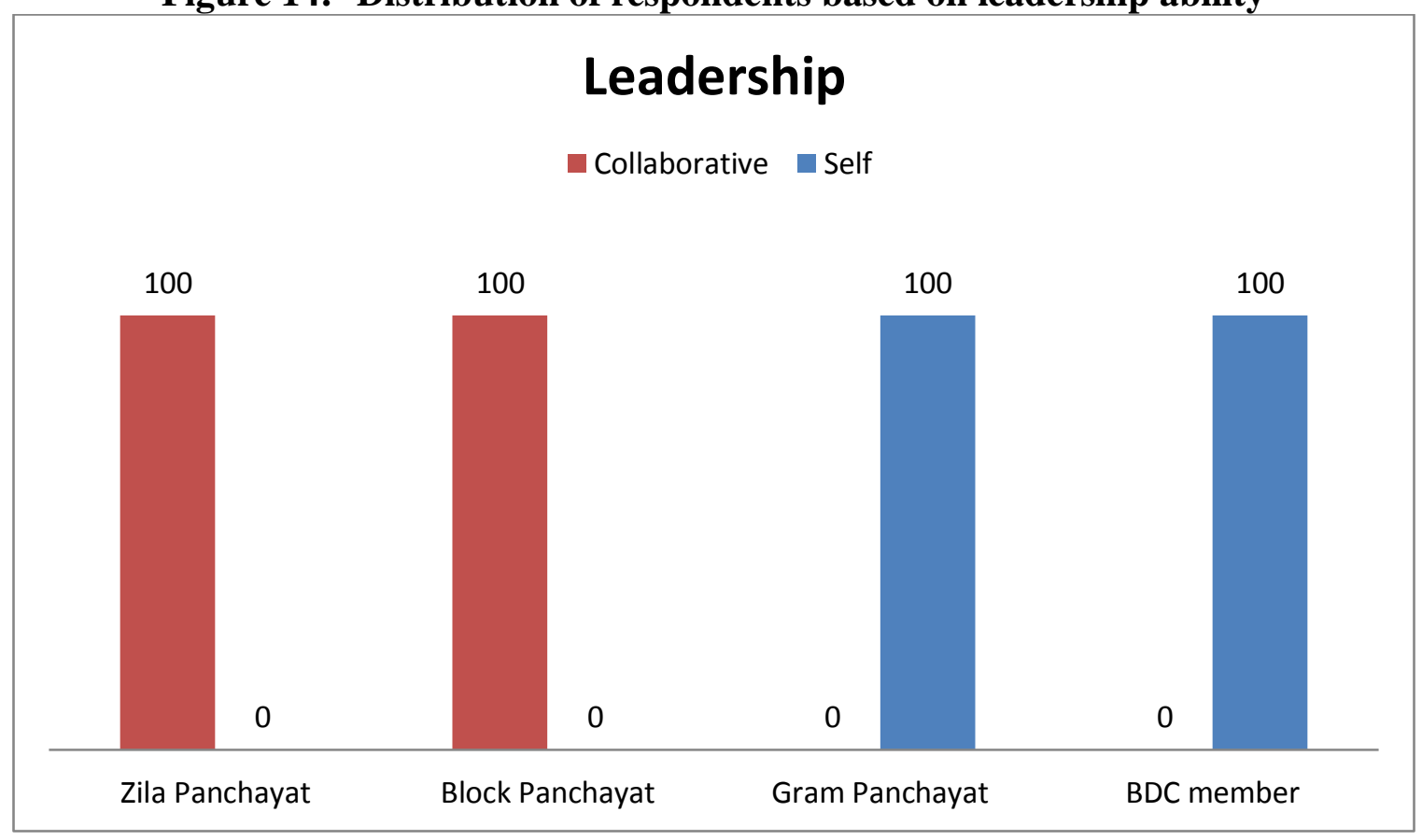




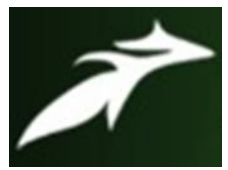

Anurag Shankar Singh et al, International Journal of Advances in Agricultural Science and Technology,

ISSN: 2348-1358

Impact Factor: 6.057

NAAS Rating: 3.77

From the data furnished in table 14 ,and graph it is concluded that $100 \%$ of respondents participated in collaborative leadership in case of Zila Panchayat, while none of them were participated in self leadership in case of Zila Panchayat. In case of Block Panchayat, none of the respondents were participated in self leadership while $100 \%$ of respondents were participated in collaborative leadership in case of Block Panchayat. 100\% of respondents were participated in self leadership while none of them were participated in collaborative leadership in terms of Gram Panchayat. In case of BDC members $100 \%$ of respondents were participated in self leadership while none of them were participated in collaborative leadership.

\section{GRAM PANCHAYAT MEMBERS ENGAGED IN FARMING}

Out of 126 respondents (GPM) total 74 respondents (GPM) were engaged in farming

\section{Crops grown by GPM}

Table 15:- Distribution of crops grown by Gram Panchayat Members

\begin{tabular}{|l|l|l|l|}
\hline S.No. & Crops & Frequency & Percentage \\
\hline $\mathbf{1}$ & Paddy+Wheat+Arhar+Maize & 35 & 47.29 \\
\hline $\mathbf{2}$ & Pea+Mustard+Gram & 16 & 21.62 \\
\hline $\mathbf{3}$ & Mung bean+Jowar+Bajra+Barley & 06 & 8.10 \\
\hline $\mathbf{4}$ & Tomato+Chilli+Okra & 11 & 14.86 \\
\hline $\mathbf{5}$ & Onion+Bitter gourd+Pumpkin & 06 & 8.10 \\
\hline & Total & $\mathbf{7 4}$ & $\mathbf{1 0 0 . 0 0}$ \\
\hline
\end{tabular}




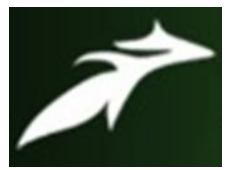

Anurag Shankar Singh et al, International Journal of Advances in Agricultural Science and Technology,

Vol.8 Issue.4, April-2021, pg. 22-52

ISSN: 2348-1358

Impact Factor: 6.057

NAAS Rating: 3.77

\title{
Figure 15:- Distribution of crops grown by Gram Panchayat Members
}

\section{Crops grown by GPM}

\author{
Paddy+ Wheat+ Arhar+ Maize $\quad$ Pea+ Mustard+ Gram \\ Mung bean+ Jowar+ Bajra+ Barley $\square$ Tomato+ Chilli+ Okra \\ Onion+ Bitter gourd+ Pumpkin
}

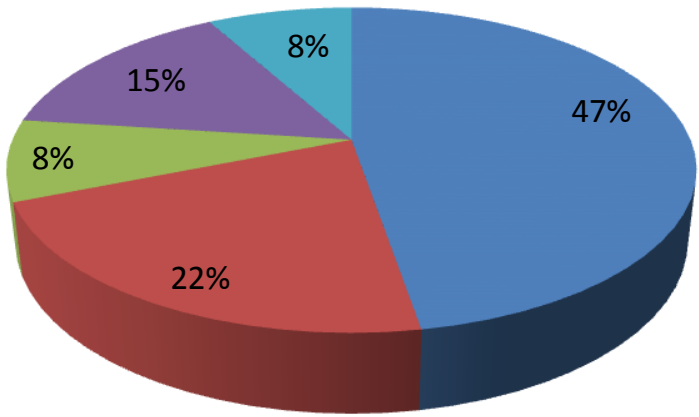

From the data furnished in table 15 and pie chart it is found that majority of respondents i.e. 47.29\% were engaged in faming of crops such as Paddy, Wheat, Arhar and Maize. 21.62\% of responds were engaged in farming of crops such as Pea, Mustard and Gram. 14.86\% of respondents were engaged in vegetable farming such as Tomato, chili and Okra. 8.10\% of respondents were engaged in farming of Mung bean, Jowar, bajra and Barley. Rest $8.10 \%$ of respondents were engaged in farming of vegetable crops such as Onion, Bitter gourd and Pumpkin. 


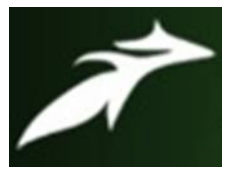

Anurag Shankar Singh et al, International Journal of Advances in Agricultural Science and Technology, Vol.8 Issue.4, April-2021, pg. 22-52

ISSN: 2348-1358

Impact Factor: 6.057

NAAS Rating: 3.77

16. Machines used by GPM

Table 16:- Distribution of machines used by Gram Panchayat Members for farming activities

\begin{tabular}{|l|l|l|l|}
\hline S.No. & Machines used for faming activities & Frequency & Percentage \\
\hline $\mathbf{1}$ & Plough & 18 & 24.32 \\
\hline $\mathbf{2}$ & Plough+Cultivator & 12 & 16.21 \\
\hline $\mathbf{3}$ & Cultivator+Xylovator & 11 & 14.86 \\
\hline $\mathbf{4}$ & Xylovator+Rotavator & 05 & 6.75 \\
\hline $\mathbf{5}$ & Rotavator+Plough & 07 & 9.45 \\
\hline $\mathbf{6}$ & Harrow+Disc harrow & 03 & 4.05 \\
\hline $\mathbf{7}$ & Plough+Harrow & 12 & 16.21 \\
\hline $\mathbf{8}$ & Plough+Hoe & 06 & 8.10 \\
\hline & Total & $\mathbf{7 4}$ & $\mathbf{1 0 0 . 0 0}$ \\
\hline
\end{tabular}

Figure 16:- Distribution of machines used by Gram Panchayat Members for farming activities

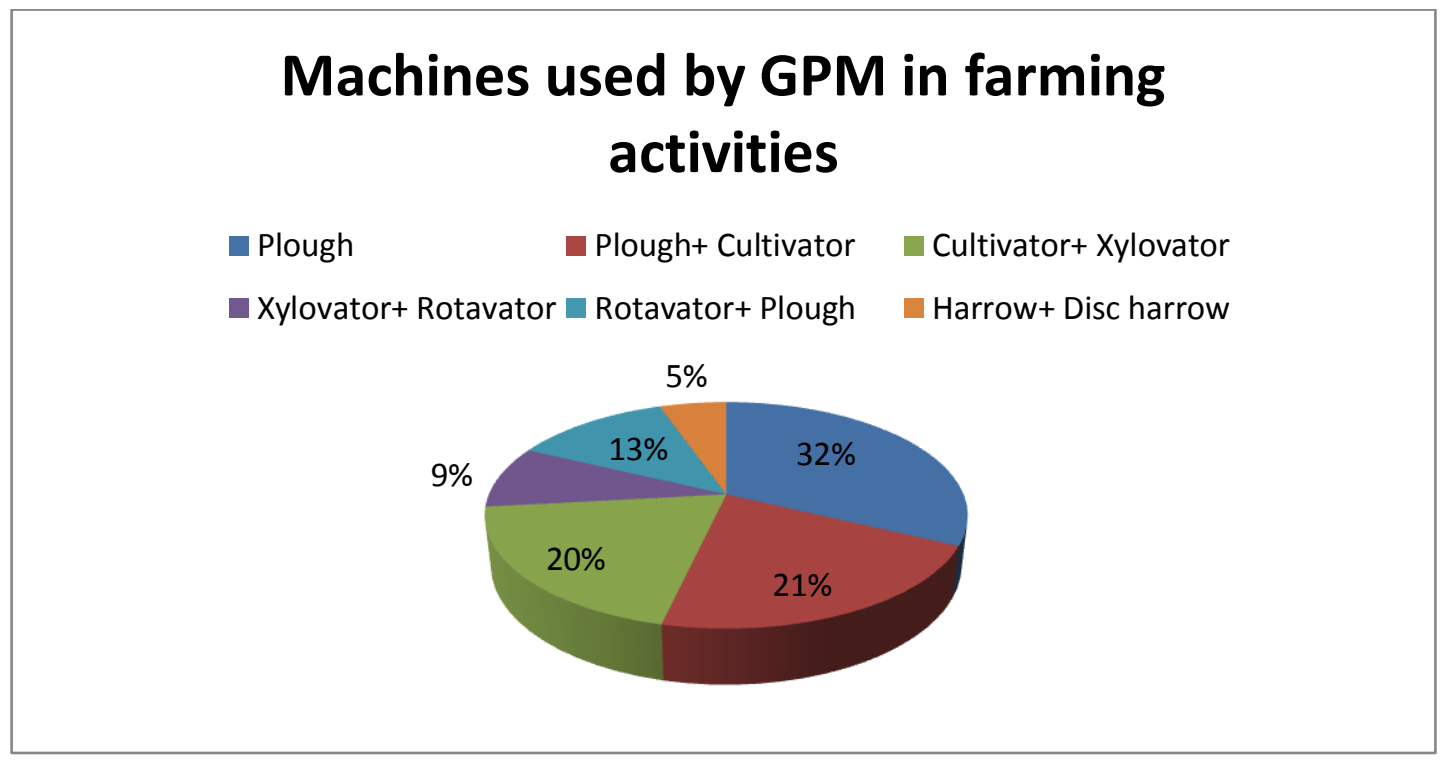




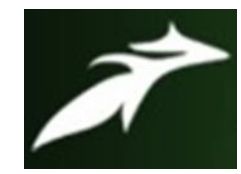

Anurag Shankar Singh et al, International Journal of Advances in Agricultural Science and Technology,

Vol.8 Issue.4, April-2021, pg. 22-52

ISSN: 2348-1358

Impact Factor: 6.057

NAAS Rating: 3.77

From the data mentioned in table 16 and pie chart it is concluded that majority i.e. $24.32 \%$ of respondents were using Plough as farming machine while $16.21 \%$ of respondents were using Plough and Cultivator collectively as farming machines. $16.21 \%$ of respondents were using Plough and Harrow collectively as farming machines followed by $14.86 \%$ of respondents were using Cultivator and Xylovator collectively as farming machines. 9.45\% of respondents were using Rotavator and Plough collectively as farming machines. 8.10\% of respondents were using Plough and Hoe as farming machines. $6.75 \%$ of respondents were using Xylovator and Rotavator collectively as farming machines. Rest $4.05 \%$ of respondents were using Harrow and Disc harrow collectively as farming machines.

\section{Fertilizers/manures used by GPM}

Table 17:- Distribution of fertilizers/manures used by Gram Panchayat Members in farming activities

\begin{tabular}{|l|l|l|l|}
\hline S.No. & Fertilizer/s and Manure & Frequency & Percentage \\
\hline $\mathbf{1}$ & Urea & 17 & 22.97 \\
\hline $\mathbf{2}$ & Urea+DAP & 39 & 52.70 \\
\hline $\mathbf{3}$ & Urea+DAP+MOP & 11 & 14.86 \\
\hline $\mathbf{4}$ & Urea+DAP+MOP+Manures & 07 & 09.45 \\
\hline & Total & $\mathbf{7 4}$ & $\mathbf{1 0 0 . 0 0}$ \\
\hline
\end{tabular}




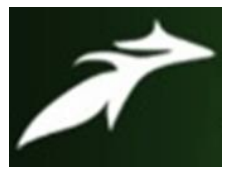

Anurag Shankar Singh et al, International Journal of Advances in Agricultural Science and Technology,

Vol.8 Issue.4, April-2021, pg. 22-52

ISSN: 2348-1358

Impact Factor: 6.057

NAAS Rating: 3.77

Figure 17:- Distribution of fertilizers/manures used by Gram Panchayat Members in farming activities

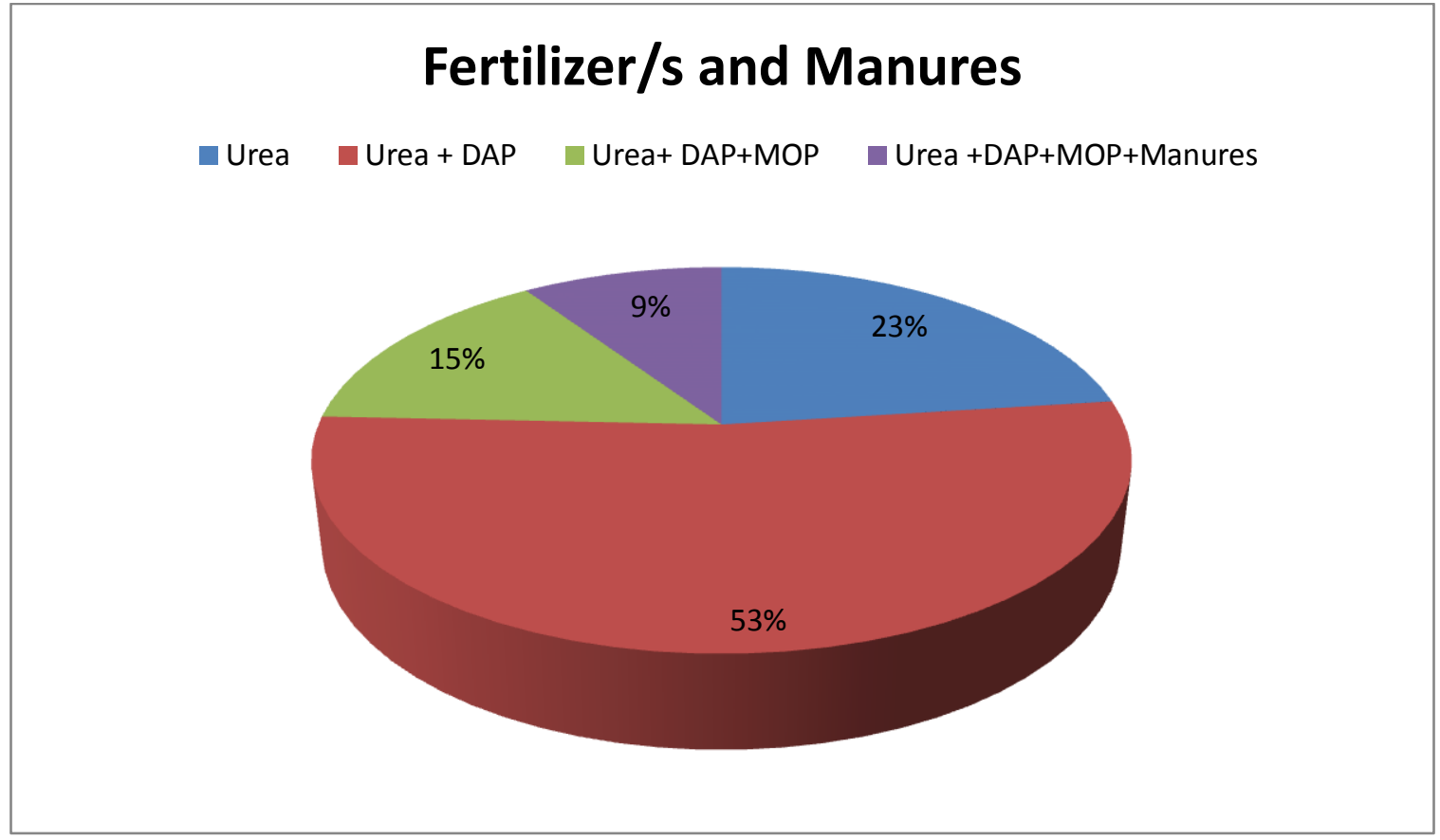

From the data furnished in table 17 and pie chart it is concluded that majority of respondents i.e. $52.70 \%$ were using Urea and DAP as fertilizers for crop production while $22.97 \%$ of respondents were using only Urea as fertilizer for crop production. $14.86 \%$ of respondents were using Urea, DAP and MOP as fertilizers for crop production while rest $9.45 \%$ of respondents were using Urea, DAP, MOP, and Manures as fertilizers and manures for crop production.

\section{Seeds used by GPM}

Table 18:- Distribution of seeds used by Gram Panchayat Members in farming activities

\begin{tabular}{|l|l|l|l|}
\hline S.No. & Seeds & Frequency & Percentage \\
\hline $\mathbf{1}$ & Desi & 03 & 4.05 \\
\hline $\mathbf{2}$ & Hybrid & 08 & 10.81 \\
\hline
\end{tabular}




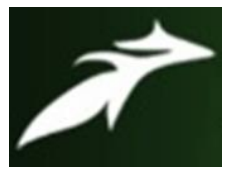

Anurag Shankar Singh et al, International Journal of Advances in Agricultural Science and Technology, Vol.8 Issue.4, April-2021, pg. 22-52

ISSN: 2348-1358

Impact Factor: 6.057

NAAS Rating: 3.77

\begin{tabular}{|l|l|l|l|}
\hline $\mathbf{3}$ & Desi+Hybrid & 63 & 85.13 \\
\hline & Total & $\mathbf{7 4}$ & $\mathbf{1 0 0 . 0 0}$ \\
\hline
\end{tabular}

Figure 18:- Distribution of seeds used by Gram Panchayat Members in farming activities

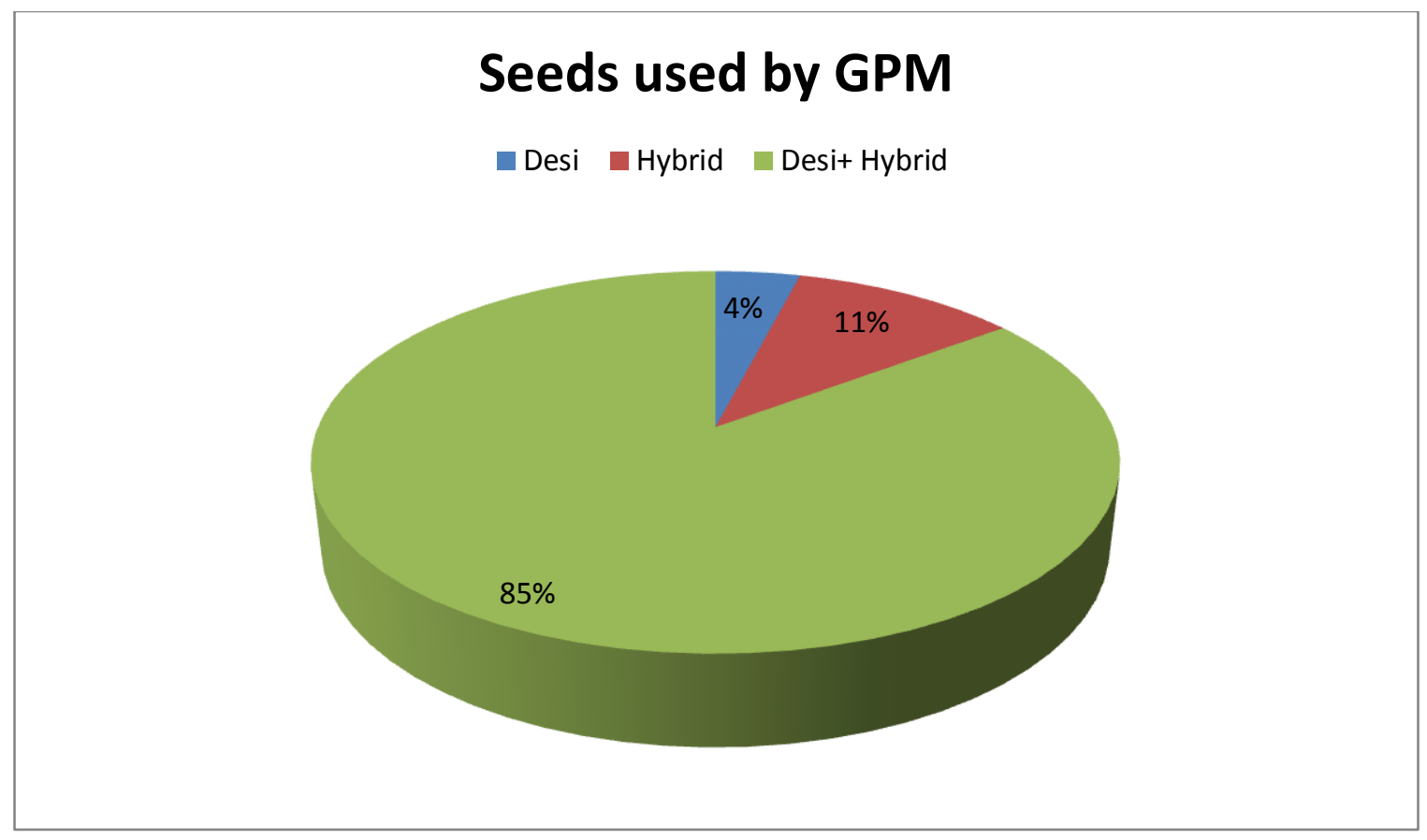

From the data furnished in table 18 and pie chart it is found that majority of respondents i.e. 85.13\% were using both Desi and Hybrid seeds for crop production while 10.81\% of respondents were using only Hybrid seeds for crop production and $4.05 \%$ of respondents were using only Desi seeds for crop production. 


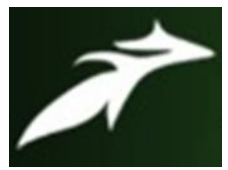

Anurag Shankar Singh et al, International Journal of Advances in Agricultural Science and Technology,

ISSN: 2348-1358

Impact Factor: 6.057

NAAS Rating: 3.77

\section{Information source}

Table 19:- Distribution of source of information used by Gram Panchayat Members in farming activities

\begin{tabular}{|l|l|l|l|}
\hline S.No. & Information source & Frequency & Percentage \\
\hline $\mathbf{1}$ & KVK & 09 & 12.16 \\
\hline $\mathbf{2}$ & ADO+ Krishi Bhawan & 07 & 09.45 \\
\hline $\mathbf{3}$ & Progressive farmers & 58 & 78.37 \\
\hline & Total & $\mathbf{7 4}$ & $\mathbf{1 0 0 . 0 0}$ \\
\hline
\end{tabular}

Figure 19:- Distribution of source of information used by Gram Panchayat Members in farming activities

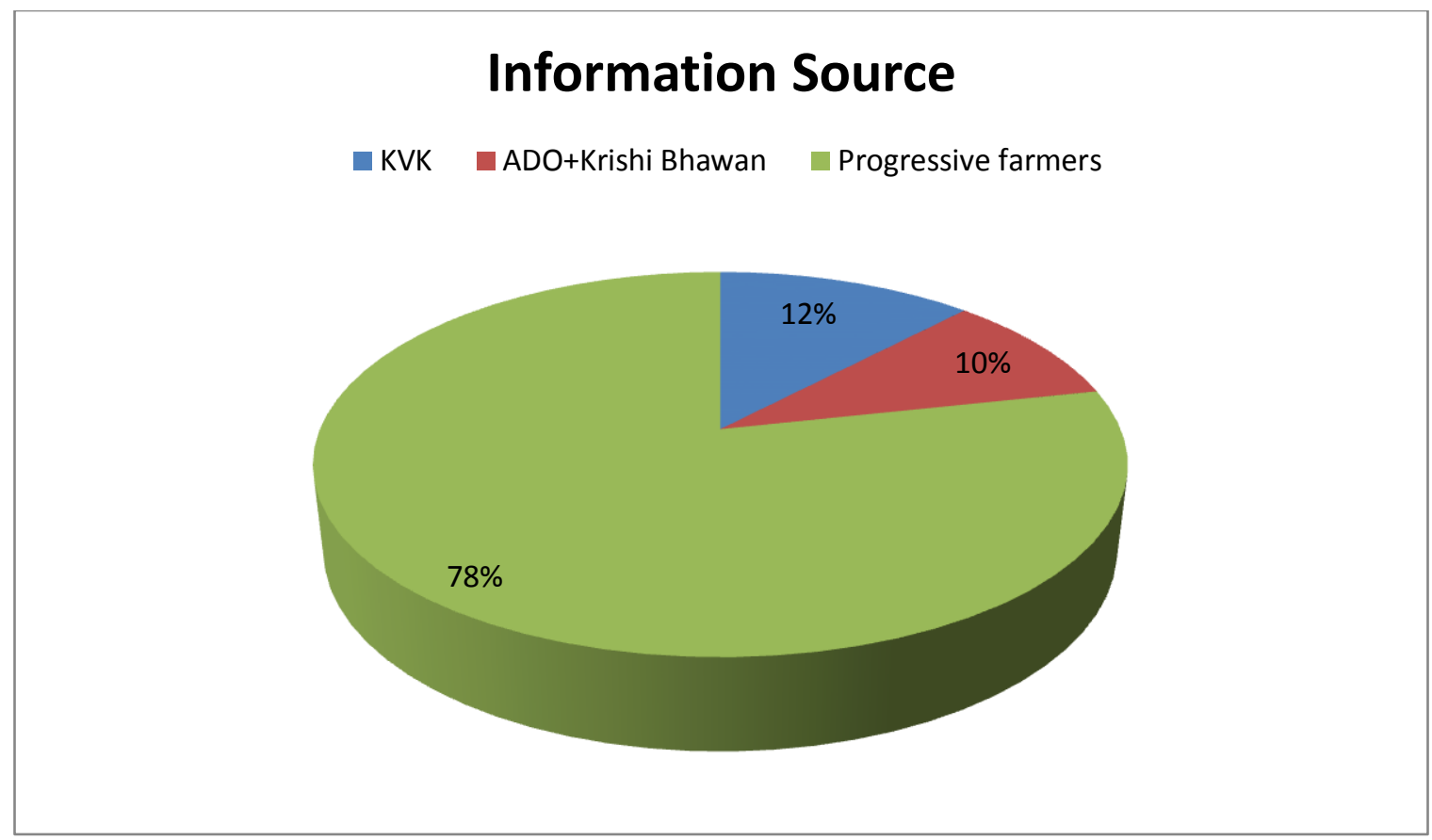

From the data furnished in table 19 and pie chart it is concluded that majority i.e. $78.37 \%$ of respondents seek information from progressive farmers while $12.16 \%$ of respondents seek 


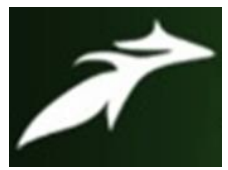

Anurag Shankar Singh et al, International Journal of Advances in Agricultural Science and Technology,

Vol.8 Issue.4, April-2021, pg. 22-52

ISSN: 2348-1358

Impact Factor: 6.057

NAAS Rating: 3.77

information from Krishi Vigyan Kendra (KVK), rest $9.45 \%$ of respondents seek information from both Agriculture Development Office (ADO) and Krishi Bhawan.

20. Agricultural input accessibility:

Table 20:- Distribution of agricultural input accessibility adopted by Gram Panchayat Members in farming activities

\begin{tabular}{|l|l|l|l|}
\hline S. No. & Input accessibility & Frequency & Percentage \\
\hline $\mathbf{1}$ & Nearby markets & 63 & 85.13 \\
\hline $\mathbf{2}$ & Others & 11 & 14.87 \\
\hline & Total & $\mathbf{7 4}$ & $\mathbf{1 0 0 . 0 0}$ \\
\hline
\end{tabular}

Figure 20:- Distribution of agricultural input accessibility adopted by Gram Panchayat Members in farming activities

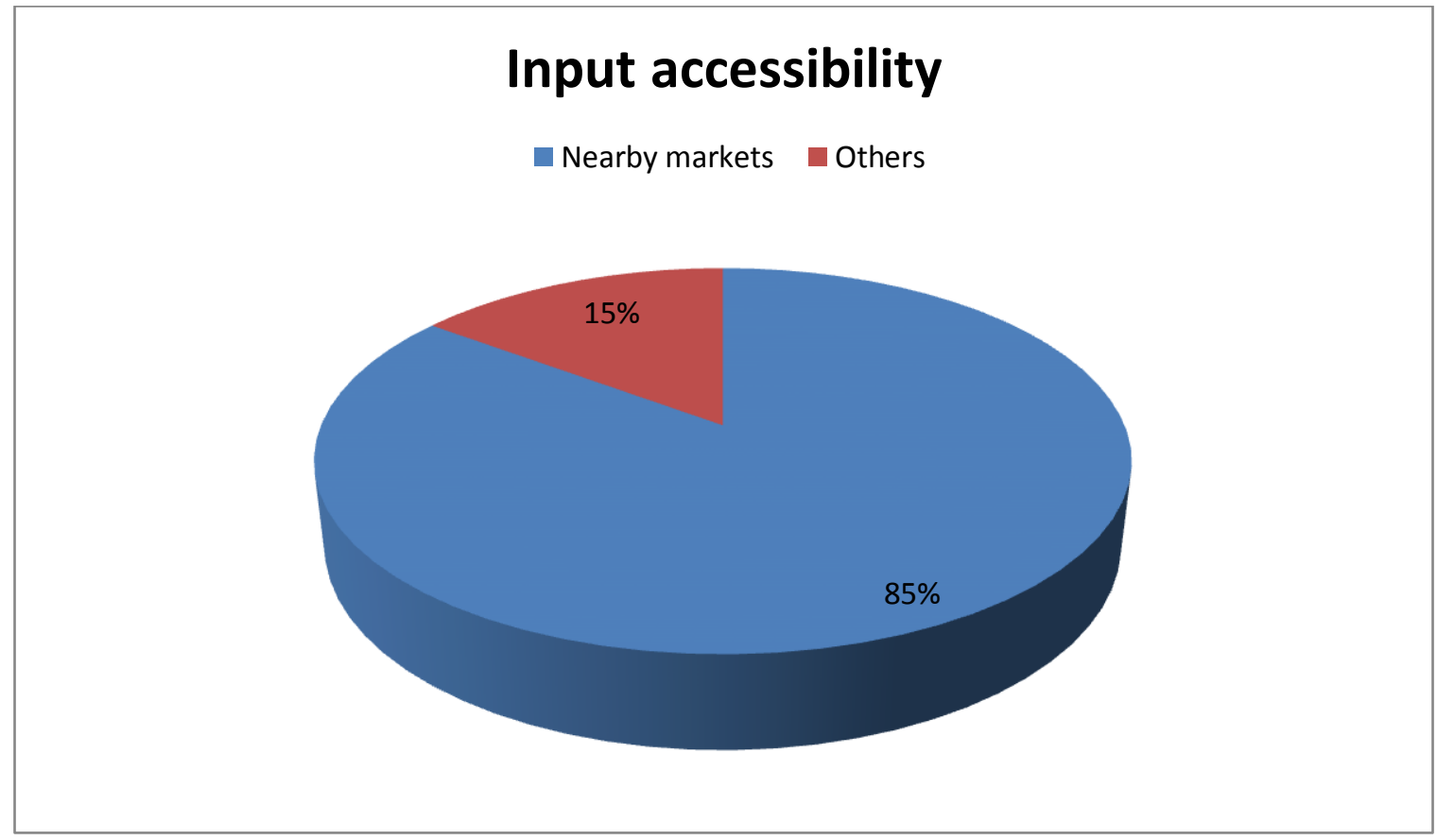




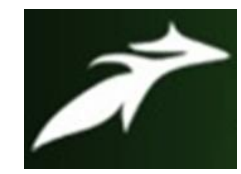

Anurag Shankar Singh et al, International Journal of Advances in Agricultural Science and Technology, Vol.8 Issue.4, April-2021, pg. 22-52

ISSN: 2348-1358

Impact Factor: 6.057

NAAS Rating: $\mathbf{3 . 7 7}$

From the data furnished in table 20 and pie chart it is concluded that majority of respondents i.e. $85.13 \%$ were getting agricultural input from nearby markets while rest $14.87 \%$ of respondents were getting agricultural input from other sources such as online, wholesale, agri store etc.

\section{CONCLUSION}

It is therefore concluded that majority of respondents i.e. $66.67 \%$ were male, $56.34 \%$ of respondents belonged to the age group of 36-55 years of age. 56.34\% of respondents belonged to General caste category, $92.85 \%$ of respondents were married. Majority of respondents i.e. $30.15 \%$ have annual income of more than 2,40,000. 26.19\% of respondents have educational qualification of Junior High School. $60.31 \%$ of respondents were having total land holding of below 1 acre. 58.73\% of respondents were having occupation of Gram Panchayat Activities (GPA) and farming. $74.60 \%$ of respondents were having nuclear family. $73.01 \%$ of respondents were having family size of up to 5 members. $60.32 \%$ of respondents were having cemented house. $100 \%$ of respondents were fully participated in Gram Panchayat activities. $77.77 \%$ of respondents never use Radio as a means of mass media exposure, $61.90 \%$ of respondents daily use newspaper as a means of mass media exposure. $100 \%$ of respondents participate in collaborative leadership in case of Zilla Panchayat \& Block Panchayat while 100\% of respondents participate in self leadership in case of Gram Panchayat \& BDC members. Majority i.e. $47.29 \%$ of respondents engaged in Paddy, Wheat, Arhar \& Maize cultivation followed by $21.62 \%$ of respondents engaged in Pea, Mustard \& Gram cultivation. $24.32 \%$ of respondents were using plough for crop cultivation followed by $16.21 \%$ of respondents were using both plough and cultivator. Majority i.e. 52.70\% of respondents were using both Urea \& DAP followed by $22.97 \%$ of respondents were using only Urea. $85.13 \%$ of respondents were using both Desi \& Hybrid seeds. $78.37 \%$ of respondents seek information from progressive farmers. Majority i.e. $85.13 \%$ of respondents were getting agricultural input from nearby markets. Majority of respondents were middle age people, having education up to junior high school and mostly dependent on farming for their income. A large sum of the respondents had very high annual income while few of the respondents had low annual income. 


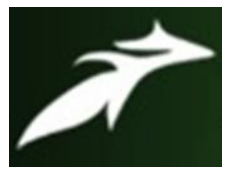

Anurag Shankar Singh et al, International Journal of Advances in Agricultural Science and Technology, Vol.8 Issue.4, April-2021, pg. 22-52

ISSN: 2348-1358

Impact Factor: 6.057

NAAS Rating: 3.77

\section{REFERENCES}

[1]. Article 40, The Constitution of India.

[2]. Baskar V. Rao. (2006). Panchayati Raj in India: Local Governance in Action for Social Development. "The Grass Root Governance Journal, IV(1)"

[3]. Bhagwat, S.M., Ankush, G.S., and Mande Jyoti v. (2010) Role performance of gram panchayat members in village development, national seminar on role of Ext. Edu. In changing Agri. Scenario souvenir and abstract, (3), Dapoli, Maharashtra.

[4]. Bhargava B. S. (1979) "Grass Roots Leadership: A Study of Leadership in Panchayat Raj Instititions” Ashish Publishing House, New Delhi.

[5]. Bhatt (2019) "Local self Government in India: A historical background, "Democratic Decentralization and Panchayati Raj in Contemporary India, Chapter 1, pp. 25.

[6]. Darshankar \& Arjun (1979) "Leadership in Panchayat Raj: A Study of Beed District of Maharashtra”, Panchasheel Prakashan, Jaipur.

[7]. Hooja, B. (1978) "Panchayat Raj versus Decentralizations of Administrations", Indian Journal of Public Administrations, Vol. XXIV, No. 3, July-Sep 1978.

[8]. Indira Hirway (1989) "Panchayat Raj at Grassroots", The Economic and Political Weekly, Vol. XXIV.

[9]. Khanna, R. I.(1966) "Panchayat Raj in Punjab and Haryana”, Mohindra Capital publishers, Sector 11-D Chandigarh.

[10].Mathur \& Sinha (1966) "Panchayat Raj in Rajasthan- A case study of Jaipur District" Impax India, New Delhi.

[11].Mishra, S.N. (1998) 'Panchayati Raj' in M. P, Indian Political System. New Delhi: Jnanada Prakashn. P. 241

[12].Preface - A Digest on Panchayat Raj (Ministry of Community Development and cooperation, Government of India, New Delhi.

[13].Report of the committee on Panchayat Raj Instititions, Government of India, New Delhi, 1978.

[14].Sharma S. (1976) "Panchayat Raj in India", Trimurti Publications, New Delhi.

[15].Singh H, (1994) "Constitutional Base for Panchayati Raj in India: The $73^{\text {rd }}$ Amendment” 34 Asian Survey 819

[16].Singh R. P.(1987) "Bihar men Gram Panchayat", Bihar Hindi Granthy Academy, Patna.

[17].Sudhakar V. (2002). New Panchayati Raj System -Local Self-Government in Community Development. Jaipur: Mangaldeep Publications.

[18]. Tiwari N. (2013) "Two decades of Panchayati Raj as Institutions of Local Self Government in India", 11 "The Grassroot governance Journal 62 


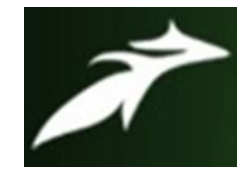

Anurag Shankar Singh et al, International Journal of Advances in Agricultural Science and Technology, Vol.8 Issue.4, April-2021, pg. 22-52

ISSN: 2348-1358

Impact Factor: 6.057

NAAS Rating: 3.77

[19]. Venkata P. Subbarao. (2009). Democratic Decentralization at Grassroot Level, Local Government Quarterly. January-March, Mumbai: All India Institute of Local SelfGovernment.

[20]. Venkatesan, V. (2002). Institutionalizing Panchayati Raj in India. New Delhi: Concept Publishing Company.

[21]. Vinod V. (2003). Panchayats, Democracy and Development. Jaipur and New Delhi: Rawat Publications. 